Carr, Dunajko, Bateman et al: New evidence for the age and palaeoecology of the Knysna Formation. Final version available at http://sajg.geoscienceworld.org/content/113/3/241.short

\title{
New evidence for the age and palaeoecology of the Knysna Formation, South Africa
} Andrew S Carr ${ }^{1}$, Adam Dunajko ${ }^{2}$, Arnoud Boom ${ }^{1}$, Mark D Bateman ${ }^{2}$, Peter J Holmes ${ }^{3}$, Juan-Carlos Berrio ${ }^{1}$

Corresponding author: A.S. Carr, asc18@le.ac.uk

1 Department of Geography, University of Leicester, UK: ab269@le.ac.uk; jcb34@le.ac.uk 2 Sheffield Centre for International Drylands Research, Department of Geography, University of Sheffield, UK: m.d.bateman@shef.ac.uk; ggp07acd@shef.ac.uk

3 Department of Geography, University of the Free State, South Africa: holmespi@ufs.ac.za

\section{Abstract}

The existence of lignitic deposits (Knysna Formation) on the South African south coast, near to the town of Knysna has been recognised for more than a century. However, a combination of limited study and few natural exposures has meant that the age and stratigraphic position of the Knysna Formation are unclear, despite its potential as a palaeoenvironmental archive. We present a new suite of chronological, geochemical and palynological data obtained from a recently identified lignite exposure in this area. The lignite pollen assemblage is dominated by palms (Arecaceae), which are now locally extinct, and contains additional palynomorphs of tropical affinity, along with (moisttemperate) Podocarpus-type pollen, grasses, and herbaceous pollen types (e.g. Cliffortia-type, Asteraceae). Overall, the assemblage shows some commonalities with the Miocene Elandsfontein Formation in the Western Cape. The lignites are dominated by a diverse range of higher plant biomarkers, including abundant leaf wax lipids, as well as lignin monomers and leaf cuticle-derived macromolecular organic matter. All strongly indicate a terrestrial depositional setting, perhaps akin to contemporary palm swamps. A number of sesquiterpenoids imply the presence of gymnosperms, supporting observations from the pollen data and previously reported macro-fossil finds.

The application of isothermal thermoluminescence techniques to coversands overlying the lignite produced a minimum age of $1.7 \mathrm{Ma}$. Additional clues as to the likely age of the lignite are provided by compound-specific stable carbon isotope analyses of the leaf wax lipids. These are approximately $8 \%$ enriched relative to typical $C_{3}$ vegetation leaf waxes, and imply a potential contribution from $C_{4}$ vegetation. From this, an age post-dating the Oligocene may be inferred, and in conjunction with the site's geomorphic setting, an age post dating the middle Miocene is considered plausible. This is markedly younger than previous (Eocene) age estimates for the Knynsa Formation. 
Carr, Dunajko, Bateman et al: New evidence for the age and palaeoecology of the Knysna Formation. Final version available at http://sajg.geoscienceworld.org/content/113/3/241.short

\section{Introduction}

Due to its progressive aridification and predominantly erosive landscape history (Partridge and Maud, 1987) southern Africa suffers from a paucity of palaeoecological evidence. The Neogene palaeoecology of the southern African flora is however of great significance and relevant to wider questions concerning patterns of floral dispersal and diversification (Coetzee, 1983; Linder, 2003), the causes and effects of the Late Neogene aridification of southern Africa, and the emergence of $C_{4}$ grasslands (Ségelan et al., 2007). The occurrence of organic-rich sediments ("lignites") near to Knysna on the southern Cape coast has been known of for more than a century (Phillips, 1927 and references therein). These are now formally recognised as the Knysna Formation (Jacobs 1992), and comprise sands, fine-grained muddy lignitic sands and lignites up to $30 \mathrm{~m}$ thick. Their relative antiquity and palaeoecological significance were easily recognised (Phillips, 1927; Du Toit, 1956). Subsequently, Thiergart et al. (1963) and Coetzee et al. (1983) reported palynological assemblages significantly different from the region's contemporary vegetation. These studies revealed the presence of extant temperate forest vegetation (e.g. Podocarpus sp., Widdringtonia cupressoides), the absence of a number of common contemporary palynomorphs (e.g. Ericaceae), and the presence of locally extinct flora (e.g. Nypa-type palm).

The extent, age and stratigraphic relationships between exposures of the Knysna Formation remain unclear, and detailed information such as sample site location has often been lacking in previous reports (e.g. Helgren and Butzer, 1977; Coetzee et al., 1983; Thwaites and Jacobs, 1987). The limited available exposure and borehole data indicate that all deposits are concentrated in the Veldmanspad and Brakenhill areas on a platform at 
Carr, Dunajko, Bateman et al: New evidence for the age and palaeoecology of the Knysna Formation. Final version available at http://sajg.geoscienceworld.org/content/113/3/241.short

altitudes more than $200 \mathrm{~m}$ above modern sea-level (Figure 1; Jacobs, 1992). This landscape setting alone implies an antiquity considerably greater than the Quaternary aged dunes and wetlands immediately seawards (Holmes et al., 2007). Age estimates based on palynological evidence (Coetzee et al., 1983) or landscape setting/stratigraphic relationships (Butzer and Helgren 1972; Helgren and Butzer 1977; Thwaites and Jacobs, 1987; Marker and Holmes, 2002; Holmes et al., 2007) are disparate, encompassing a range between the Eocene and the Miocene.

In the course of recent investigations into the origin and distribution of the Knysna coversands, Holmes et al (2007) reported a 2-3 m thick sandy lignite deposit beneath a $15 \mathrm{~m}$ sequence of aeolian coversands at Makhulu Quarry, c. $4 \mathrm{~km}$ southeast of Veldmanspad (Figures 1 and 2). Optically stimulated luminescence (OSL) dating of the coversands produced a minimum age of $>500 \mathrm{ka}$, but the underlying lignite was not investigated. The aims of the present paper are:

1. Following initial attempts at OSL dating (Holmes et al., 2007), to reassess the age of the coversands at Makhulu Quarry using recently developed isothermal thermoluminescence (ITL) techniques. (Choi et al., 2006; Jain et al., 2007; Vandenberghe et al., 2009).

2. To analyse the organic geochemistry and palaeoecology of the lignite exposed at Makhulu in order to infer its likely depositional context and palaeoenvironment/palaeoecology.

3. To set the palaeoecological data in the context of palynological (Cole and Roberts, 1996; Scott, 1995) and palaeoecological (Hopley et al., 2007; Ségelan et al., 2007) evidence for southern African flora. 
Carr, Dunajko, Bateman et al: New evidence for the age and palaeoecology of the Knysna Formation.

Final version available at http://sajg.geoscienceworld.org/content/113/3/241.short

Figure 1: Site locations in the Wilderness-Knysna region shown in relation to the mapped coversand distribution (modified from Marker and Holmes, 2002). The broad locations of previous lignite exposures (Brakenhill and Veldmanspad) are also shown.

86

87

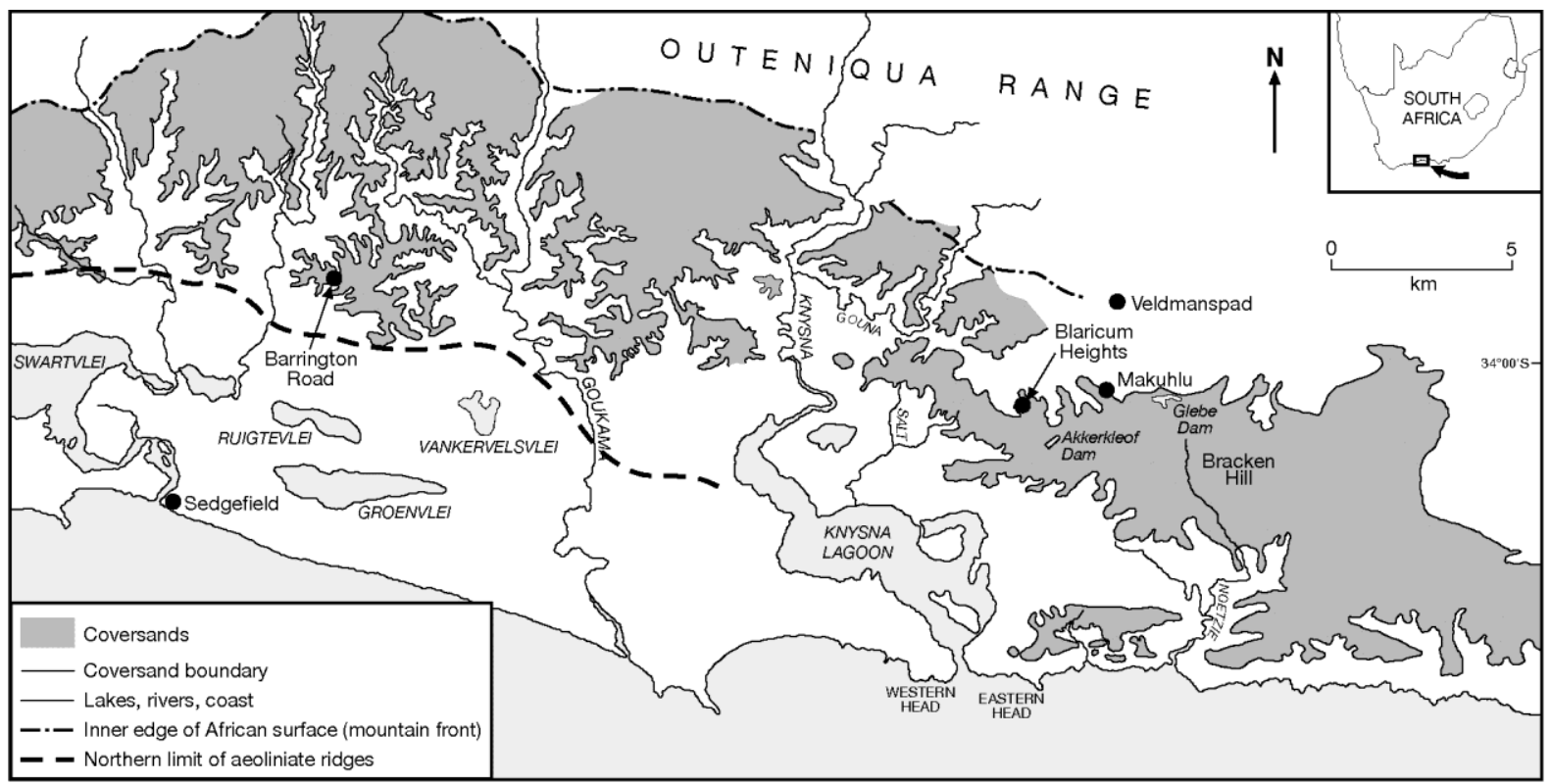

\section{Site description and stratigraphic setting}

Samples were obtained from Makhulu Quarry in $2004\left(34^{\circ} 00^{\prime} 48^{\prime \prime} \mathrm{S} 23^{\circ} 06^{\prime} 26^{\prime \prime} \mathrm{E}\right.$;

altitude $220 \mathrm{~m}$ above modern sea-level [amsl]) which lies northeast of Knysna, and close to

the northern limits of the Knysna coversands mapped by Marker and Holmes (2002). The stratigraphy of the site (which since sampling has been fully excavated) is shown in Figure 2 .

The site lies within a hollow in the underlying Peninsula Formation (Table Mountain Group)

bedrock topography, which probably accounts for the enhanced thickness of the sand in this location (Holmes et al., 2007). Up to $3 \mathrm{~m}$ of sandy lignites unconformably overlie the Peninsula Formation quartzites and are themselves overlain by up to $15 \mathrm{~m}$ of weathered and ferrugenised coversand deposits. Holmes et al. (2007) considered this the southern Cape coversand type site and provided a detailed description of the coversand properties. 
Carr, Dunajko, Bateman et al: New evidence for the age and palaeoecology of the Knysna Formation. Final version available at http://sajg.geoscienceworld.org/content/113/3/241.short

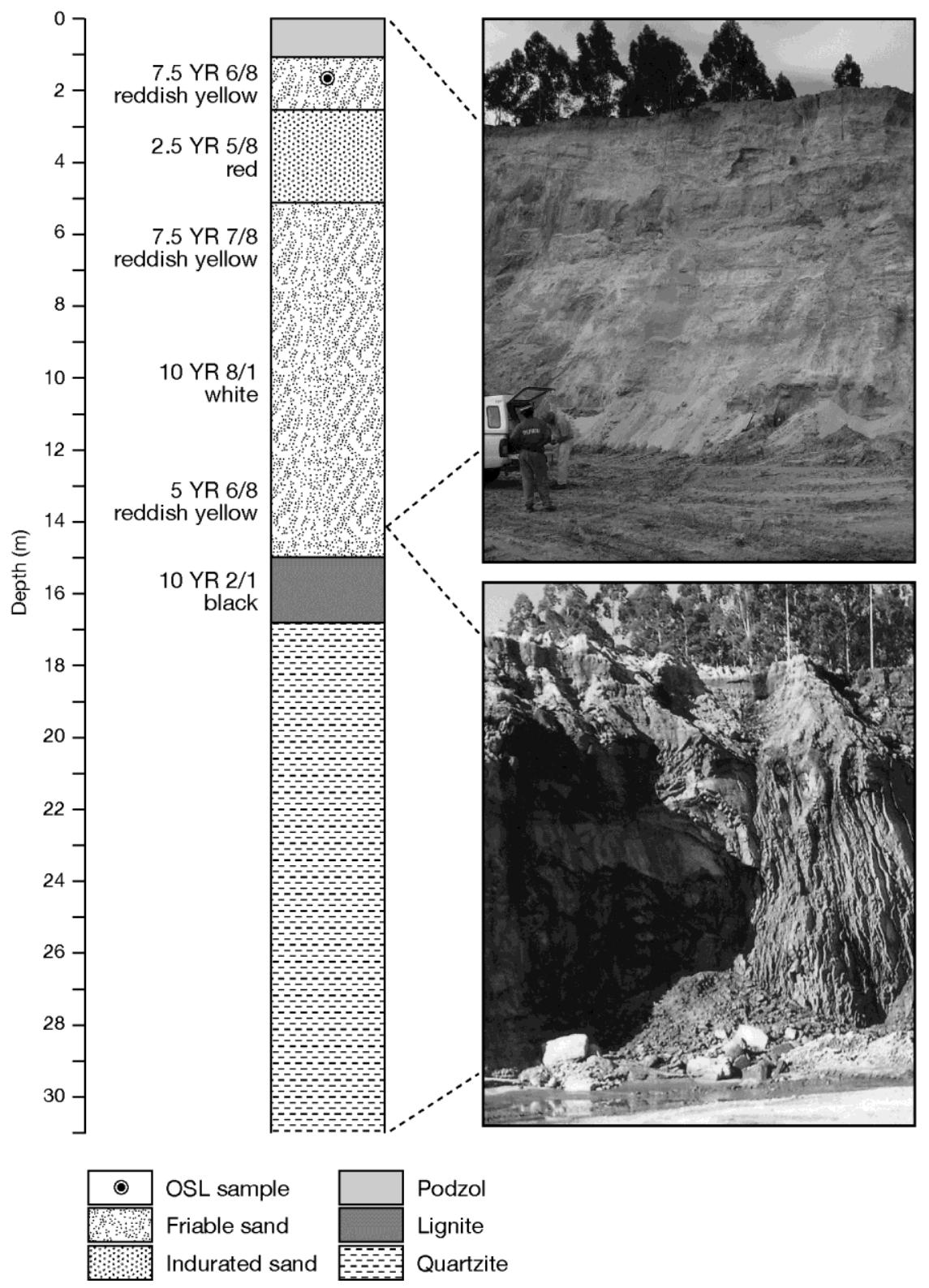

103 Figure 2: Site stratigraphy and photographs of Makhulu Quarry (in 2004). The location of the OSL sample reported by Holmes et al., (2007) and re-evaluated in this study is shown. Note in upper photograph the laterisation of the coversands (at c. 3-5 m depth) and in the lower photograph the lignite/coversand contact. 
Carr, Dunajko, Bateman et al: New evidence for the age and palaeoecology of the Knysna Formation. Final version available at http://sajg.geoscienceworld.org/content/113/3/241.short

\section{Geochronology}

Optically stimulated luminescence (OSL) of quartz has been widely used in the southern Cape to date mid to late-Pleistocene marine and aeolian sediment (e.g. Bateman et al., 2004). The fundamental principle is that buried quartz acts as a dosimeter, storing up trapped electrons in its crystal lattice in proportion to the natural (geological) radioactivity in the environment (Aitken 1985). If buried for sufficient time quartz grains become 'saturated' (lattice cannot accommodate additional free electrons), which constrains the upper limit of the technique. The time to saturation is largely a function of background radioactivity and in low radiation environments reliable OSL ages approaching 500 ka have been determined (Banerjee et al., 2003). Holmes et al. (2007) found that the coversands in the Makhulu Quarry and the nearby Blaricum Heights site (Figure 1) were saturated using standard OSL techniques and obtained minimum ages of $>500 \mathrm{ka}$ and $>300$ ka respectively (Figure 2).

In this study we re-analyse one of the Makhulu samples reported by Holmes et al. (2007), using an isothermal thermoluminescence (ITL) dating approach which seeks to overcome the saturation issues previously encountered (Choi et al., 2006). While most OSL dating relies on measuring electrons immediately evicted on optical stimulation (the 'fast component' of the luminescence signal; Wintle and Murray, 2006), quartz grains also emit a thermoluminescence (TL) signal upon heating, with peaks at $325^{\circ} \mathrm{C}$ and $375^{\circ} \mathrm{C}$ (Aitken, 1985 ). New ITL dating protocols utilise a single aliquot regenerative dose (SAR) protocol akin to standard OSL dating, but measure only the signal emitted from the $325^{\circ} \mathrm{C}$ TL peak, which is known to be bleached by visible light (Franklin, 1997). Crucially, this signal saturates at much higher doses than the OSL fast component. For instance, Jain et al. (2005) recorded a near 
Carr, Dunajko, Bateman et al: New evidence for the age and palaeoecology of the Knysna Formation. Final version available at http://sajg.geoscienceworld.org/content/113/3/241.short

order of magnitude increase in the saturation dose of quartz grains using ITL compared to OSL. There is thus potential for ITL to be used to date sediments beyond the range of conventional OSL dating, which would be of significance given the extensive Neogene marine and aeolian deposits along the Western Cape coastline.

\section{Methods}

Luminescence sampling, quartz sample extraction and dose rate determinations followed Holmes et al. (2007). All luminescence measurements were carried out on a Ris $\varnothing$ luminescence reader using $9.6 \mathrm{~mm}$ diameter aliquots with luminescence signals detected through a Hoya U340 filter. Previous studies have employed a range of temperatures for both the ITL stimulation and the sample preheat (Choi et al., 2006; Buylaert et al., 2006; and Huot et al., 2006). To establish the applicability of ITL to the deposits in this study the protocol was first tested using a coversand sample (Shfd08191 from Barrington Road, $33^{\circ}$ $59^{\prime} 13 \mathrm{~S}, 22^{\circ} 51^{\prime} 08 \mathrm{E} ; 90 \mathrm{~m}$ amsl; Figure 1) which was within the range of the standard SAR OSL approach (equivalent dose of c. $240 \mathrm{~Gy}$ ). For this sample SAR OSL equivalent doses $\left(D_{\mathrm{e}}\right)$ were determined following Murray and Wintle (2000), with ITL $D_{\mathrm{e}}$ values at both $300^{\circ} \mathrm{C}$ and $310^{\circ} \mathrm{C}$ determined for a range of preheat temperatures $\left(240^{\circ} \mathrm{C}\right.$ to $270^{\circ} \mathrm{C}$ in $10^{\circ} \mathrm{C}$ increments; Choi et al., 2006; Table 1). For sample Shfd08191 ITL $D_{\mathrm{e}} \mathrm{S}$ obtained at $310^{\circ} \mathrm{C}$ were consistently closer to the OSL $D_{e}$ than those obtained using ITL at $300^{\circ} \mathrm{C}$ (Figure 3 ). The measurements at $310^{\circ} \mathrm{C}$ also produce a $D_{\mathrm{e}}$ plateau at preheats of $260^{\circ} \mathrm{C}$ and below. Based on these results, an ITL stimulation temperature of $310^{\circ} \mathrm{C}$ and a preheat temperature of $260^{\circ} \mathrm{C}$ were selected for full ITL measurement of the sample. Growth curves were fitted with a saturating exponential function (Figure 4). For the purposes of subsequent age estimation 
Carr, Dunajko, Bateman et al: New evidence for the age and palaeoecology of the Knysna Formation. Final version available at http://sajg.geoscienceworld.org/content/113/3/241.short

all aliquots with a recycling ratio outside $1 \pm 0.2$ were rejected prior to $D_{e}$ calculation. Sunlight bleaching of the ITL signal was tested by exposing seven aliquots of the Makhulu Quarry sample (Shfd04287) to (UK) daylight for 1 week. A residual ITL $D_{e}$ of $4.73 \pm 0.34 \mathrm{~Gy}$ $(n=7)$ was determined (Figure 5a; Table 2), which given the magnitude of the sample equivalent doses, was considered small enough to be of negligible significance. For the Makhulu sample (Shfd04287) 24 aliquots were measured using an ITL stimulation temperature of $300^{\circ} \mathrm{C}$ and a preheat temperature of $260^{\circ} \mathrm{C}$ (determined experimentally in an identical manner to the above). Table 2 shows the finalised OSL and ITL $D_{e}$ values used for age calculation reported with 1 sigma uncertainties.

\section{Results}

For Shfd08191 (Barrington Road), the mean $D_{e}$ values from the OSL and ITL approaches are broadly similar and are within 1 standard deviation of each other $\left(O S L D_{e}=\right.$ $242 \pm 30 ;$ ITL $D_{e}=295 \pm 50$; Figure 5). The slightly higher mean $D_{e}$ for ITL results may reflect a signal contribution from TL traps incompletely bleached by sunlight prior to burial (Figures 5b and 5c). More significantly in the context of the coversands, while the OSL growth curves typically saturate at $350 \pm 50$ Gy (Figure 4a), the ITL growth curves grow beyond 550 Gy (Figure 4b). As such, and given the favourable comparison of ITL to OSL data, it is inferred that the ITL procedure can provide new age constraints on Knysna coversand material beyond those presented by Holmes et al (2007). ITL measurements on the Makhulu quarry sample (Shfd04287) reveal the naturally acquired ITL signal to be very large (Figure 6) and for two aliquots this was significantly higher than the maximum administered laboratory dose, which prevented interpolation. These aliquots were rejected from 
Carr, Dunajko, Bateman et al: New evidence for the age and palaeoecology of the Knysna Formation. Final version available at http://sajg.geoscienceworld.org/content/113/3/241.short

(a)

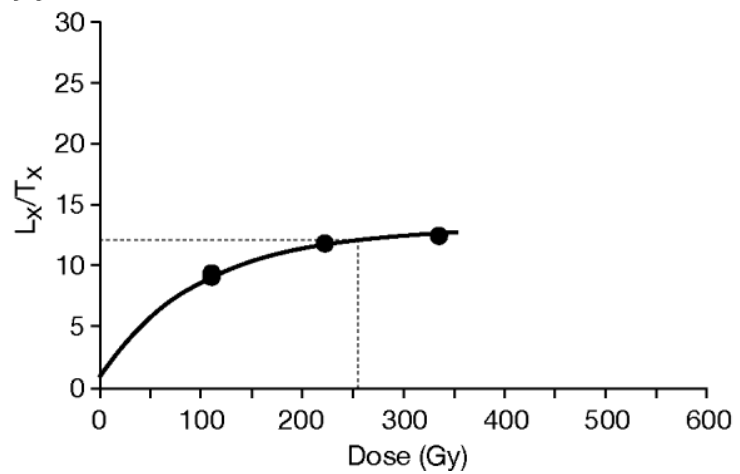

(b)

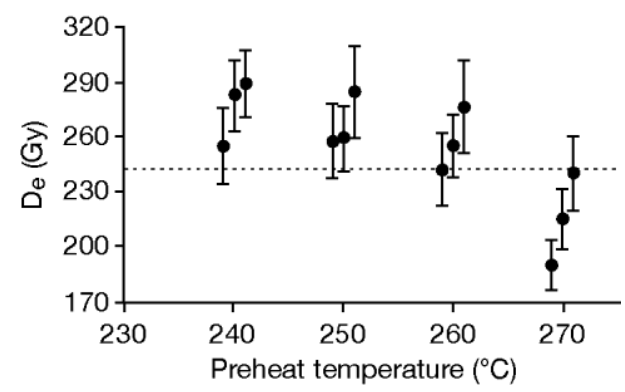

Figure 3: Preheat plateau tests undertaken to establish the optimum ITL stimulation and preheat temperatures for sample Shfd08191: (a) ITL at $300^{\circ} \mathrm{C}$ (b) ITL at $310^{\circ} \mathrm{C}$. Dashed line shows $D_{e}$ of sample established using conventional SAR OSL. Note for clarity aliquots measured at the same preheat temperatures are slightly offset.

(a)

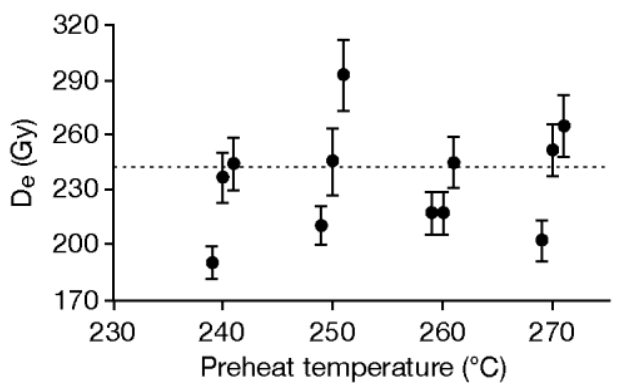

y). The remaining 10 aliquots, for which a $D_{e}$ could Gy (Figure $5 \mathrm{~d}$ ), from which an age of $1.7 \pm$ 0.14 Ma was derived (Table 2). With $40 \%$ of the aliquots measured by ITL in saturation this is clearly a minimum $D_{e}$ and thus, age estimate for the coversand (and lignite) at this site. It is however more than triple the minimum age obtained via SAR OSL (Holmes et al., 2007) and it suggests a pre-Quaternary antiquity for both the coversands and the underlying lignite.

(b)

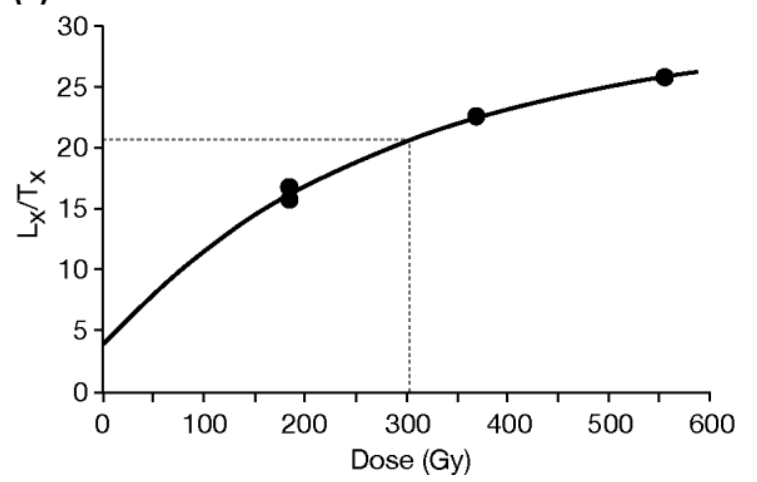

Figure 4: Example growth curves for individual aliquots from sample Shfd08191: (a) OSL and (b) ITL 
Carr, Dunajko, Bateman et al: New evidence for the age and palaeoecology of the Knysna Formation. Final version available at http://sajg.geoscienceworld.org/content/113/3/241.short

196

(a)

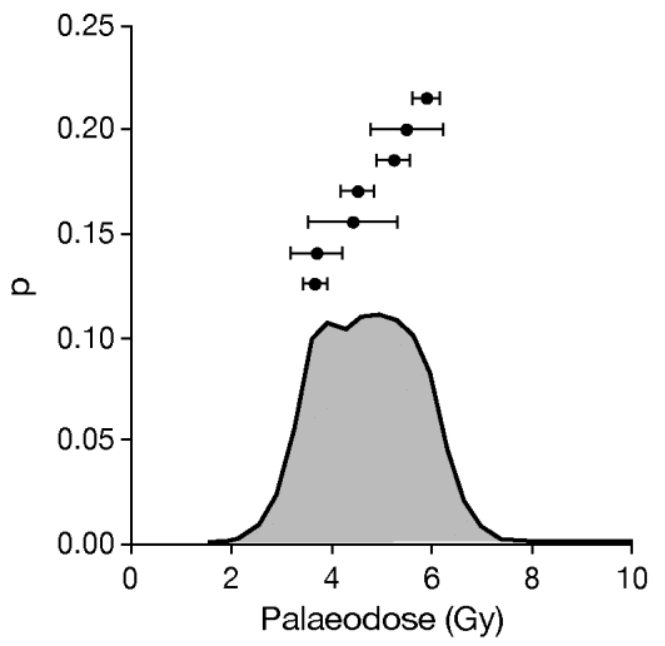

(c)

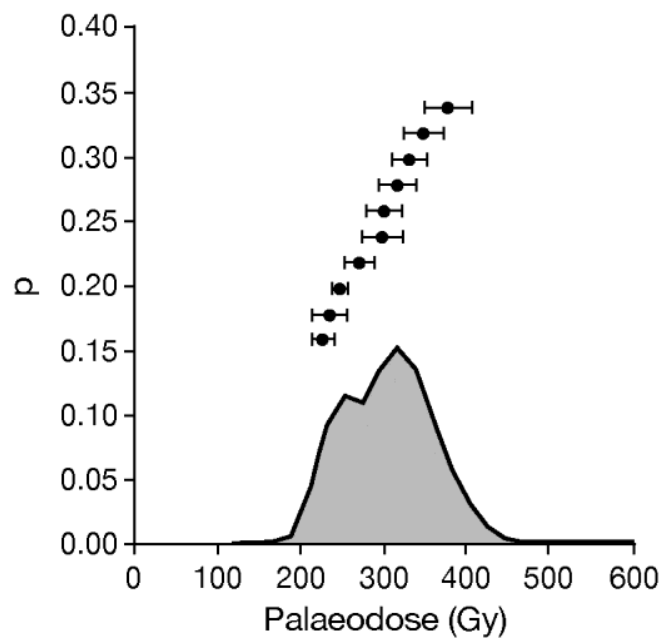

(b)

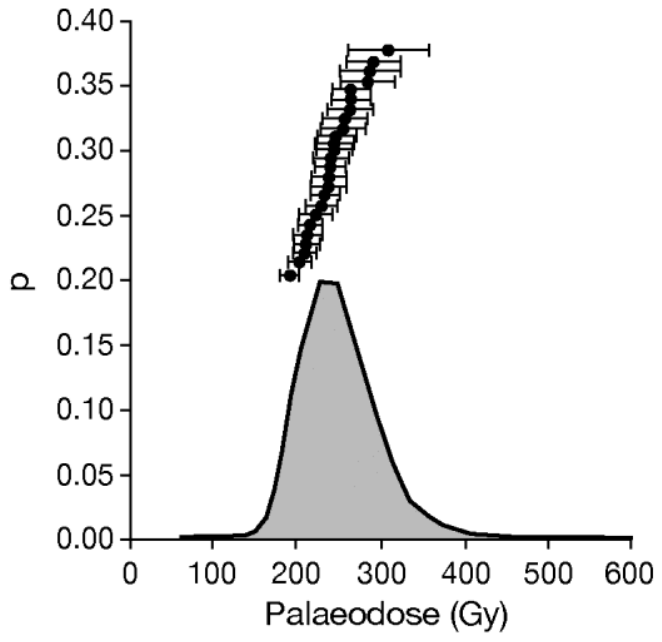

(d)

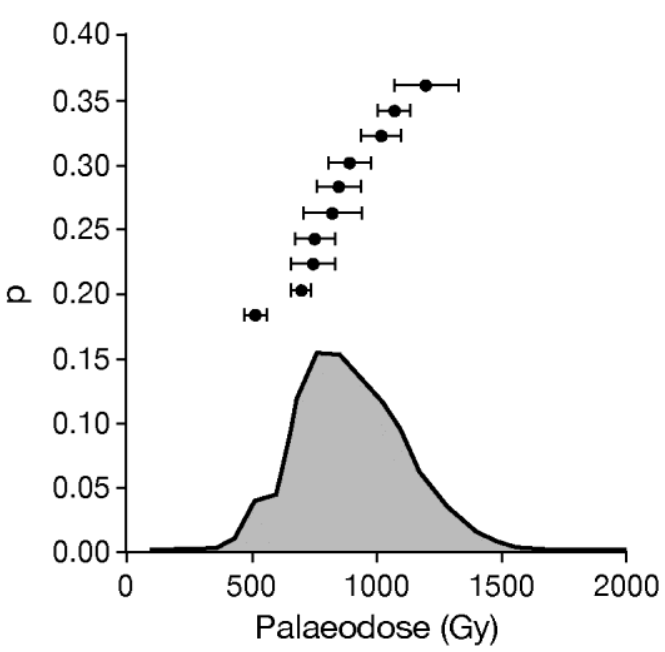

197

Figure 5: $D_{e}$ distributions of samples measured (a) ITL of sample Shfd04287 after exposure to daylight for seven days. Average $D_{e}=4.73 \pm 0.34 \mathrm{~Gy}$ (b) OSL $D_{e}$ distribution for sample Shfd08191 from Barrington Road (c) ITL $D_{e}$ distribution for sample Shfd08191 from Barrington Road (d) ITL $D_{e}$ distribution for sample Shfd04287 from Makhulu Quarry. 
Carr, Dunajko, Bateman et al: New evidence for the age and palaeoecology of the Knysna Formation. Final version available at http://sajg.geoscienceworld.org/content/113/3/241.short

(a)

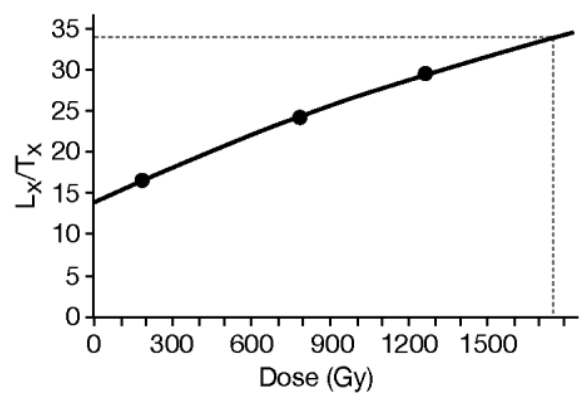

(b)

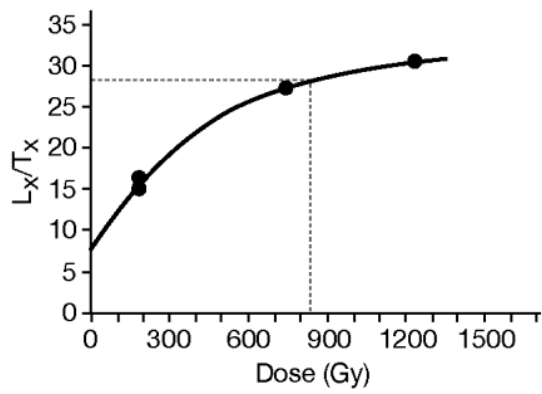

204

205

206

207

208

209

210

211

212

213

214

215

216

217

218

219

220

221

222

223

Figure 6: Example ITL growth curves for sample Shfd04287

\section{Organic geochemistry}

The last two decades have seen the rapid development of palaeoecological and palaeoenvironmental approaches using biomarkers (see Eglinton and Eglinton, 2008 for an overview). Suites of biomarkers within organic matter reflect the composition of the original inputs to a sample (e.g. local ecology) and the effects of subsequent microbial and diagenetic degradation. In this study we have applied solvent-extractable lipid analyses, and pyrolysis-GC/MS (py-GC/MS) analyses to the Makhulu lignite. The pyrolysis technique provides insights into the origin and diagenetic alteration of insoluble macromolecular organic matter (e.g. lignin) within a sample. Using these techniques we assess the Makhulu depositional setting, the extent of organic matter preservation/diagenesis, and the palaeoenvironmental setting of the site. These new data are interpreted in light of accompanying palynological analyses, and potential points of comparison for future lignite finds are noted.

\section{Methods}

The sampled lignite was freeze dried and homogenised prior to analysis. Total $\mathrm{C}$ and $\mathrm{N}$ data were measured using a SerCon ANCA GSL elemental analyser connected to a SerCon 
Carr, Dunajko, Bateman et al: New evidence for the age and palaeoecology of the Knysna Formation. Final version available at http://sajg.geoscienceworld.org/content/113/3/241.short

224 Hydra 20-20 continuous flow isotope ratio mass spectrometer (cf-IR-MS). Solventextractable lipid biomarkers were extracted using a series of solvents of progressively decreasing polarity (methanol; dichloromethane (DCM); hexane). Extracts were eluted over an $\mathrm{Al}_{2} \mathrm{O}_{3}$ column to derive apolar and polar fractions. The polar fractions were derivatized using bis(trimethylsilyl)trifluoroacetamide (BSTFA) for 1 hour at $60^{\circ} \mathrm{C}$ prior to analysis. GC/MS analyses were carried out on a Perkin Elmer Clarus 500 GC-MS system fitted with a CP-Sil 5CB MS column (30 $\mathrm{m} \times 0.25 \mathrm{~mm}$ ). Compounds were identified on the basis of their retention times and mass spectra. Compound specific stable isotope analyses were conducted on the apolar solvent fraction using an Agilent 6890N gas chromatograph equipped with a combustion reactor, interfaced to a SerCon GC-CP which was connected to the Hydra 20-20 cf-IR-MS. Results are presented as an average of three solvent injections with accompanying standard deviations (better than $0.5 \%$ for all reported compounds). Pyrolysis GC/MS was conducted using a CDS 1000 pyroprobe coupled to the Perkin Elmer Clarus 500 GC-MS system. Approximately $0.5 \mathrm{mg}$ of sample was encapsulated in a quartz tube and held in place with quartz wool. The sample was then pyrolysed at $610^{\circ} \mathrm{C}$ for 15 seconds. Measurements were conducted on an untreated sample, as well as the residue remaining following saponification (reflux in $\mathrm{KOH}$ and methanol). This process hydrolyses certain chemical bonds (ester bonds), and assists in characterising the original nature of the macromolecular organic matter (some macromolecules will be resistant to this process).

\section{Results}

The total organic carbon (TOC), total nitrogen (TN) and $\delta^{13} \mathrm{C}_{\mathrm{TOC}}$ of the lignite are shown in Table 3. The TOC/TN ratio is very high (45) and suggestive of organic matter 
Carr, Dunajko, Bateman et al: New evidence for the age and palaeoecology of the Knysna Formation. Final version available at http://sajg.geoscienceworld.org/content/113/3/241.short

247 dominated by terrestrial / higher plant-derived organic matter, as opposed to algal-rich 248 lacustrine organic matter, which typically exhibits lower TOC/TN ratios (4-10; Meyers and 249 Lallier-Vergès, 1999). These data are consistent with Phillip's (1927) observations of wellpreserved plant macro-fossils within the lignite.
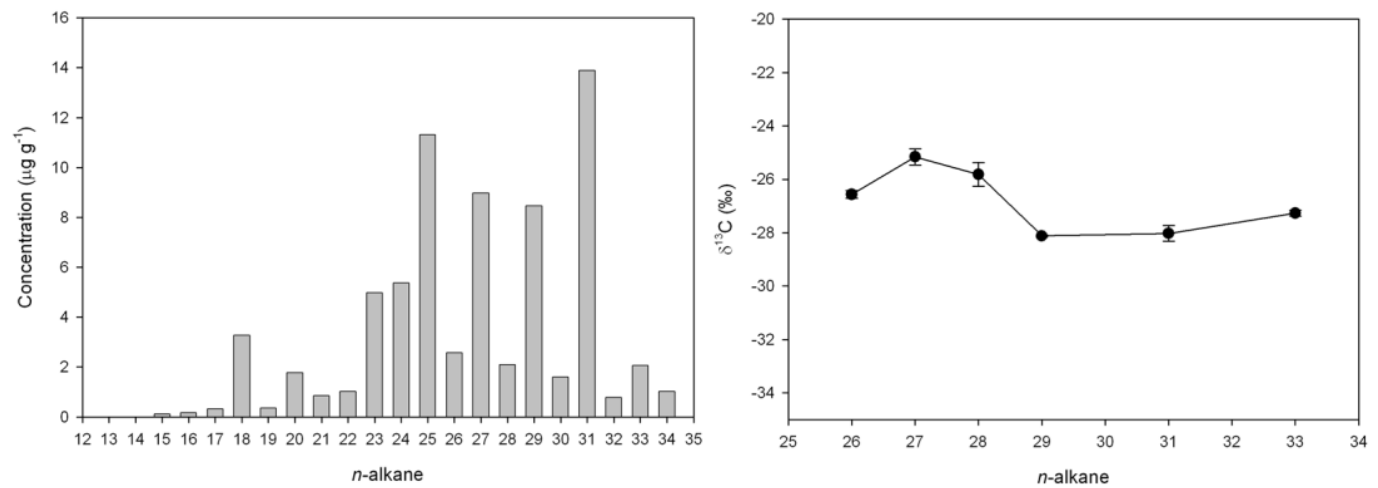

251

252

253 Figure 7: The $n$-alkane distribution (absolute concentrations) and $n$-alkane $\delta^{13} \mathrm{C}$ values obtained from 254 the apolar solvent extract. End member $n$-alkane $\delta^{13} C$ values for $C_{3}$ and $C_{4}$ vegetation are typically 255 $20 \%$ and $-35 \%$ respectively (Boom et al., 2002).

256 
Carr, Dunajko, Bateman et al: New evidence for the age and palaeoecology of the Knysna Formation. Final version available at http://sajg.geoscienceworld.org/content/113/3/241.short

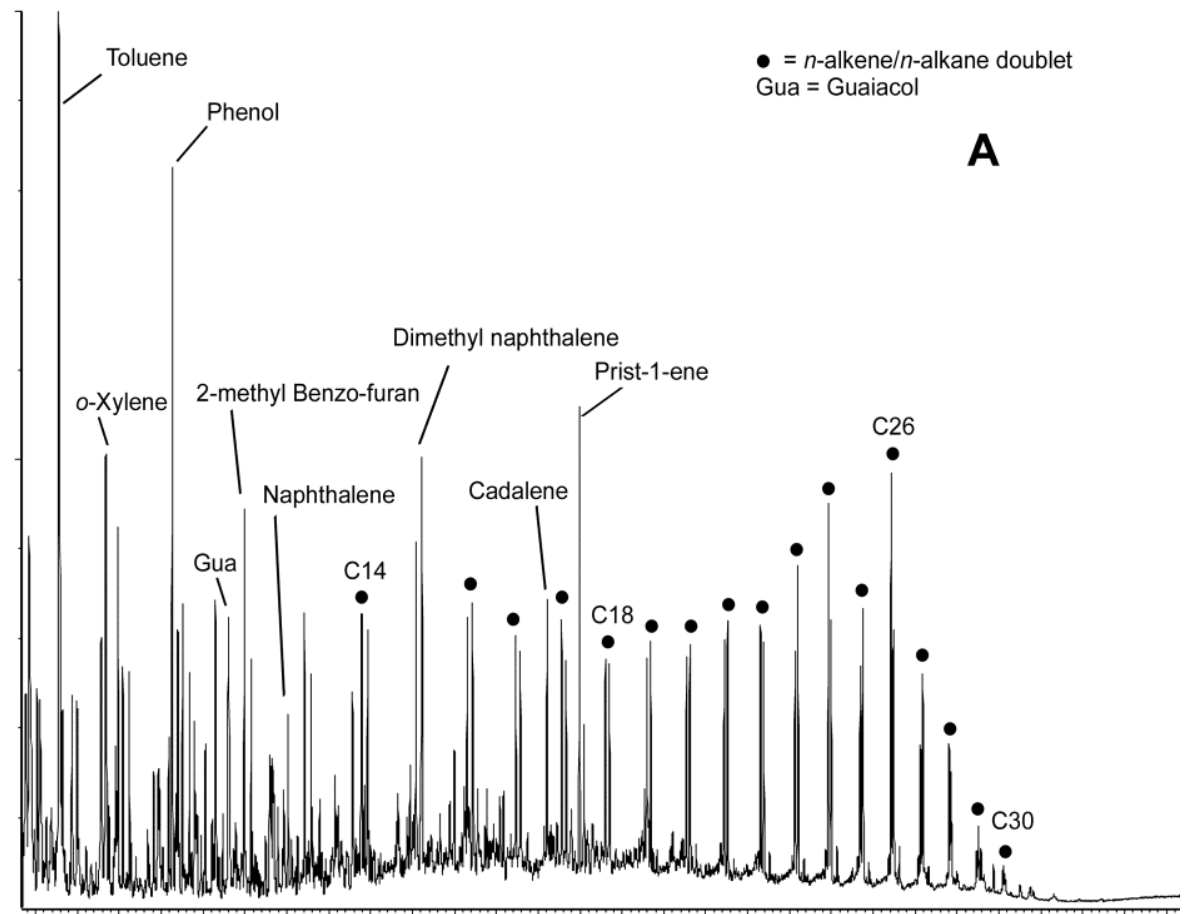

B

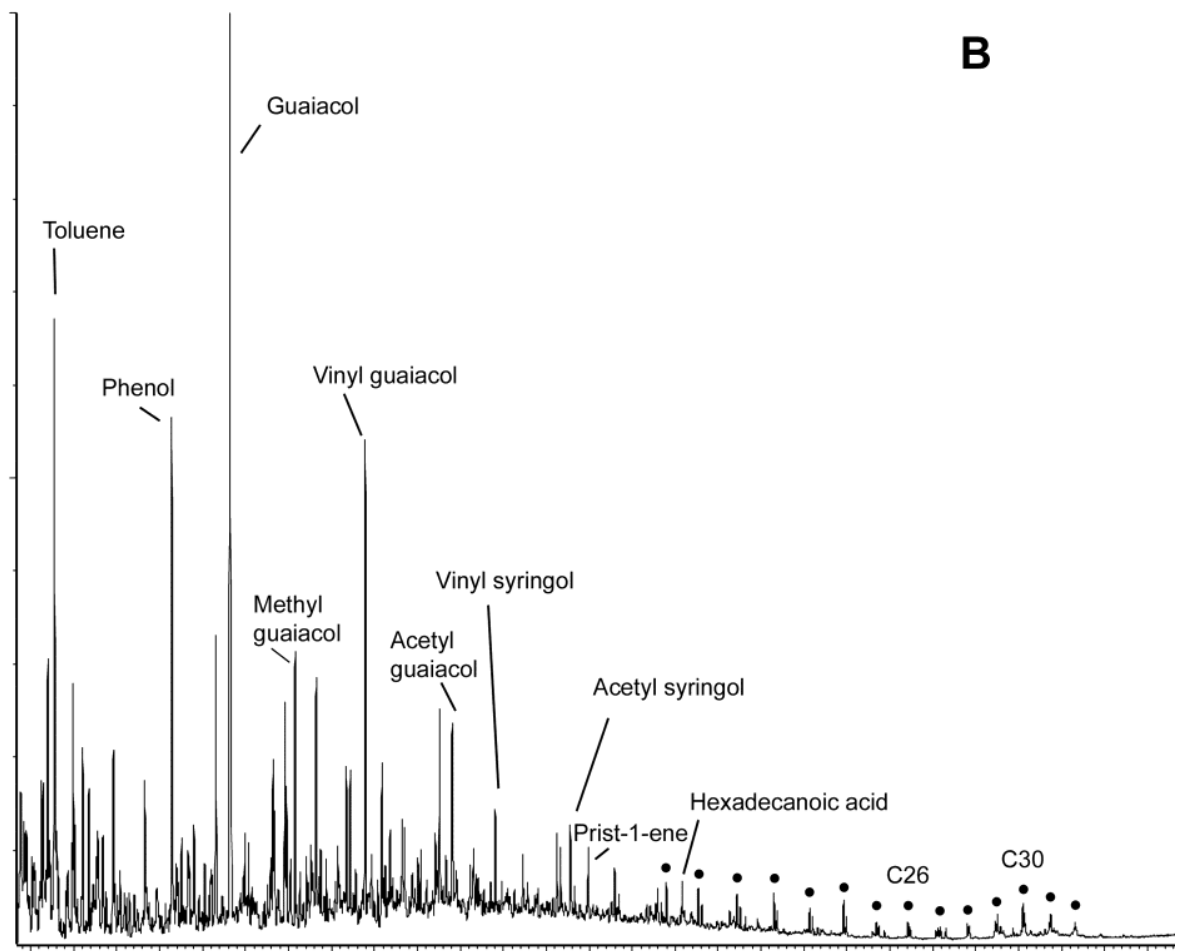

Figure 8: Pyrograms (total ion current) of (A) Knysna lignite and (B) contemporary wetland sediments from Still Bay area. Peak heights are normalised to the highest peak in each sample. The GC programme comprised an initial temperature of $40^{\circ} \mathrm{C}$ for 1.8 minutes, ramped to a final temperature of $310^{\circ} \mathrm{C}$ at $4^{\circ} \mathrm{C} \mathrm{min}-1$ which was held for 20 minutes. Major peaks are labelled (with chain length indicated where appropriate) with selected structures shown 
Carr, Dunajko, Bateman et al: New evidence for the age and palaeoecology of the Knysna Formation. Final version available at http://sajg.geoscienceworld.org/content/113/3/241.short The extractable lipids comprise a homologous series of $n$-alkanes, pentacyclic triterpenoids and des-A-triterpenoids (des-A-Lupane and Olean-12-ene) in the apolar extract, and a homologous series of $n$-alkanols $\left(C_{16}-C_{28}\right)$, as well as the compounds $\beta$-amyrin (olean-12-en-3 $\beta$-ol), $\alpha$-amyrin and friedelan-3-one in the polar extracts. The $n$-alkane distribution (Figure 7) is bi-modal, peaking at $C_{25}$ and $C_{31}$. $n$-alkanes in the range $C_{27}$ to $C_{33}$ are generally considered to derive from higher plant epicuticular leaf waxes (Eglinton and Hamilton, 1967) and as observed here, are characterised by odd over even chain length dominance (expressed as the carbon preference index; ' $\mathrm{CPI}$ '). A secondary peak is seen within the mid chain length $n$-alkanes $\left(C_{21}\right.$ to $\left.C_{25}\right)$. These shorter odd chain length $n$-alkanes $\left(\mathrm{C}_{23}\right.$ and $\mathrm{C}_{25}$ ) have been associated with submerged or floating plants, rather than terrestrial plants or emergent macrophytes such as Typha and Phragmites (Ficken et al., 2000). This distinction forms the basis of the $\mathrm{P}_{\mathrm{aq}}$ index, which is used to assess the relative significance of submerged, emergent or terrestrial vegetation (Ficken et al., 2000). The $P_{\text {aq }}$ value of 0.42 for the Makhulu lignite is transitional between terrestrial vegetation / emergent macrophytes (typically 0.1-0.4) and submerged / floating plant matter (typically $0.4-1.0$ ). This interpretation implies the presence of some floating/aquatic vegetation, and potentially a partially open water environment. (Bechtel et al., 2002; Stefanova et al., 2005). These are typical coal biomarkers and are common constituents of resins from the Podocarpaceae, Cupressaceae and Pinaceae families (Otto et al., 2005). In this case the sesquiterpendoids extracted from Makhulu cannot be associated with any individual plant family, but their occurrence strongly suggests the presence of gymnosperm vegetation in the site vicinity. Similarly, although most lipid 
Carr, Dunajko, Bateman et al: New evidence for the age and palaeoecology of the Knysna Formation. Final version available at http://sajg.geoscienceworld.org/content/113/3/241.short

biomarkers are indicative of a higher plant (angiosperm) origin, none can be used as chemotaxonomic indicators (e.g. Pancost and Boot, 2004).

The other major constituents of the lipid extracts are hopanes, and their diagenetic isomers, moretanes, which are typically derived from bacterial activity and are common in many lignite deposits (e.g. Bechtel et al., 2002; Bechtel et al., 2003; Otto et al., 2005). Here they are dominated by $17 \beta-22,29,30$ trisnorhopane and $17 \beta 21 \alpha$-homomoretane. Hop17(21)-ene is also present. Diagenetically immature samples are dominated by hopanes in the (biological) $17 \beta 21 \beta$ isomeric configuration (Pancost et al., 2007) and the presence of some hopanes in the $17 \alpha 21 \beta$ configuration reveals the occurrence of minor diagenetic alteration.

The lignite pyrolysate (i.e. solvent insoluble OM) is shown in Figure $\mathbf{8 A}$, with surface sediment from a contemporary southern Cape wetland for comparison (Figure 8B). The Makhulu lignite is dominated by aromatic and aliphatic compounds, with the latter, which comprise a series of long chain $\left(C_{8}\right.$ to $\left.C_{32}\right) n$-alkene/n-alkane doublets, accounting for $52 \%$ of the total ion current (TIC) and peaking at chain lengths of $C_{10}-C_{15}$, and $C_{21}$ to $C_{26}$. These aliphatics are substantially more significant in the lignite than in the modern sample $<19 \%$ of TIC). They may be derived from a range of potential biological sources, including cutin, a biopolymer derived from leaf cuticles, which may be preserved in samples of a geological antiquity (Logan et al. 1993). Other potential sources include cutan, a resistant biopolymer derived from certain plant cuticles (Nip et al., 1989; Boom et al., 2005), algaenan, which is derived from some freshwater algae (Blokker et al., 1998), and geo-polymers formed postdeposition (Yang et al., 2005; Gupta et al. 2007). The pyrolysate of the saponified residue reveals a reduction in the significance of the doublets longer than $\mathrm{C}_{24}$, implying the presence 
Carr, Dunajko, Bateman et al: New evidence for the age and palaeoecology of the Knysna Formation. Final version available at http://sajg.geoscienceworld.org/content/113/3/241.short

311 of cutin monomers (Logan et al., 1993). A residual aliphatic signal remains, and given the

312 lack of evidence for algal organic matter in the sample (e.g. high TOC/TN ratio, the low

313 significance of short chain alkanes, and the absence of specific algal biomarkers) this most

314 likely represents a plant-derived macromolecule (e.g. cutan) and/or a post-depositional geo-

315 polymer. The former source is of interest given the isolation of cutan in the leaves of extant

316 Podocarpus sp. (Boom et al., 2005), and the occurrence of macro-remains of Podocarpus in

317 the Knysna Formation (Phillips, 1927). In conjunction, a number of lignin pyrolysis products

318 were identified, which are of a lower relative significance and diversity $(0.8 \% \mathrm{TIC})$ than the

319 modern sample (c. $30 \%$ of TIC). This probably reflects the aerobic degradation of lignin. The

320 lignin monomers are dominated by guaiacol and degradation is implied by both the lack of

321 alkylated guaiacol lignin monomers and the trace amounts of (less resistant) sinapyl-derived

322 lignin monomers.

Compound specific stable isotopes

Inferring terrestrial palaeoenvironmenta from bulk stable isotope data in lacustrine contexts may be complicated by the incorporation of biomass from multiple sources (Street-

327 Perrott et al., 2004). Due to their wide distribution within the atmosphere (Conte and Weber, 2002) the isotopic signature of leaf wax lipids can provide useful insights into regional palaeoecological conditions (Boom et al., 2002). The $\delta^{13} \mathrm{C}$ values determined for the $C_{27}$ to $C_{33} n$-alkanes in the Makhulu lignite fall between -25 and $-28 \%$ (weighted mean $\delta^{13} \mathrm{C}$

$-27.0 \%$; Figure 7 and Table 4). The dominance of the $C_{31}$ alkane and the depletion of the 
Carr, Dunajko, Bateman et al: New evidence for the age and palaeoecology of the Knysna Formation. Final version available at http://sajg.geoscienceworld.org/content/113/3/241.short

isotopic ratios are substantially more enriched than leaf waxes derived from pure $C_{3}$ vegetation (typical $\delta^{13} \mathrm{C}$ of $-35 \%$; Collister et al., 1994; Boom et al., 2002).

Compound specific $\delta^{13} \mathrm{C}$ measurements on the bacterially-derived hopanes (Table 4) reveal slight enrichment $(-20$ and $-25 \%$ ) relative to the bulk organic matter $(-26.6 \%)$. This has been observed in both contemporary wetlands and Palaeogene lignites (Pancost et al., 2007). The hopane $\delta^{13} \mathrm{C}$ values do not indicate anaerobic conditions (ibid), which is consistent with the py-GC/MS data for the (aerobic) degradation of lignin. Similarly, there is no evidence for anaerobic methane oxidation (e.g. depleted hopane $\delta^{13} \mathrm{C}$ values).

\section{Palynological analysis}

Palynomorphs (Figure 9 and Table 5) are abundant in the Makhulu lignite, but are often poorly preserved ( $8 \%$ were damaged or unidentifiable). From a count of 250 palynomorphs the sampled assemblage is dominated by palms (37\%). Poaceae $(4.6 \%$, ) Cyperaceae (6.7 \%) and Podocarpus-type pollen (3.8\%) are also frequently identified. The palm (Arecaceae) pollen is mostly monosulcate in form, preventing easy associated with a single family or subfamily (e.g. Harley and Baker, 2001). Pollen from typical fynbos vegetation is mostly lacking (e.g. Ericaceae). One palynomorph closely resembling the Rosaceae genus Cliffortia was identified, along with pollen resembling Anthospermum-type (Rubiaceae) and two examples of a small tricolporate palynomorph akin to Grubbiaceae. One triporate palynomorph with a triangular amb potentially represents Proteaceae. Asteraceae pollen (2.9\%) of the Vernonia and Asteroideae types was identified (e.g. Scott, 
Carr, Dunajko, Bateman et al: New evidence for the age and palaeoecology of the Knysna Formation. Final version available at http://sajg.geoscienceworld.org/content/113/3/241.short

1982; Skvarla et al., 2005). A number of palynomorphs were of unclear affinity, the most common being a tetracolporate grain $(6.7 \%)$, resembling pollen from the family Sapotaceae

(Figure 9), and a tetraporate grain (5\%) resembling the pollen of Symphonia (Clusiaceae;

Figure 9). Pollen resembling the latter type has also been identified in Miocene sediments from the Angola Basin (Partridge, 1978). In the contemporary tropics (South America, West

Africa, and Madagascar) this genus is often riparian or found within palm swamps (Ledru,
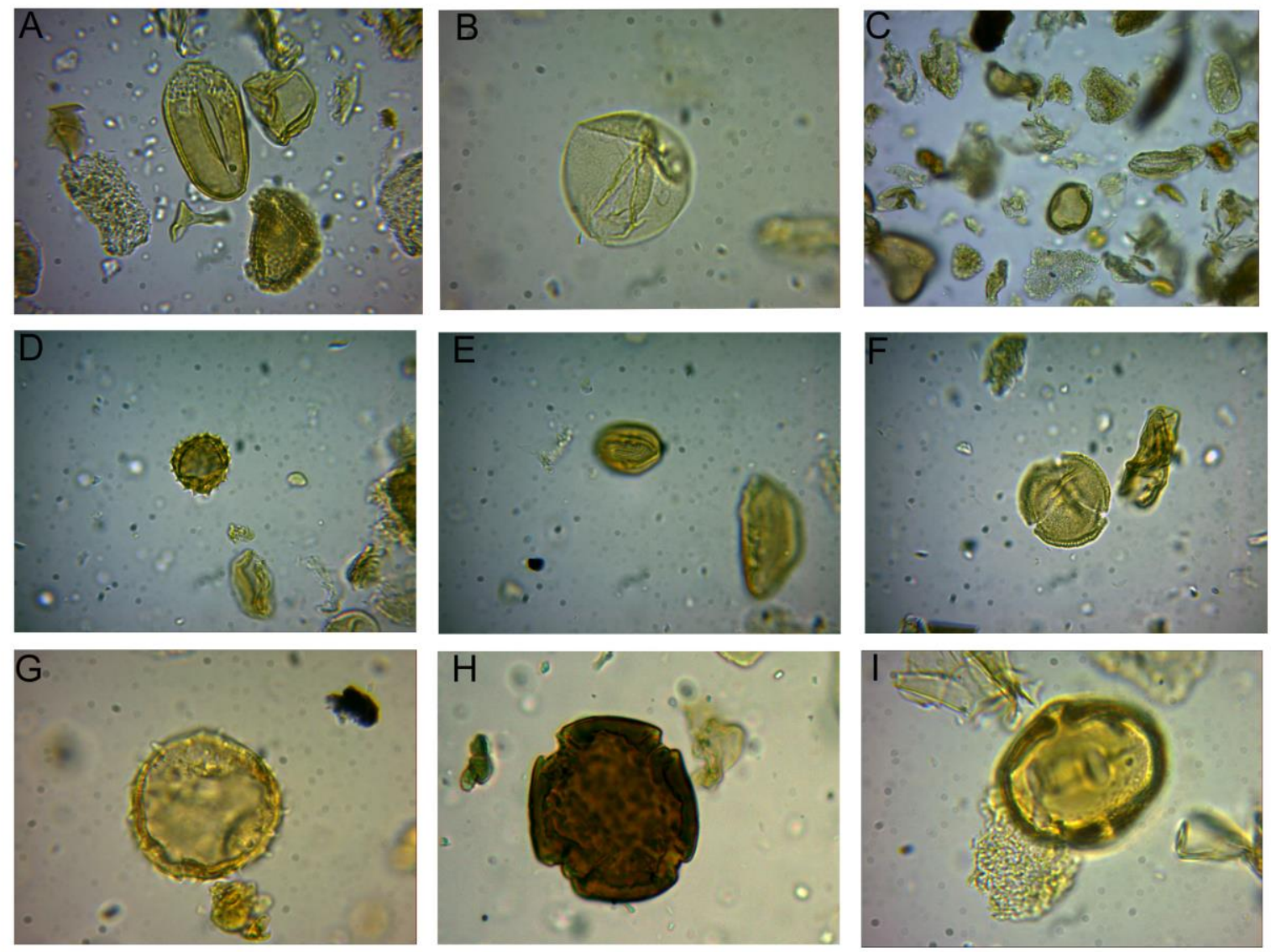

Figure 9: Photograph montage of key pollen types identified within the sample A: Palm; B: Poaceae;

367 C: Cliffortia-type; D: Asteraceae; E: Rhus-type; F: Rubiaceae(?); G: Malvaceae; H: Symphonia-type; I 368 Tetracolporites (Sapotaceae). 
Carr, Dunajko, Bateman et al: New evidence for the age and palaeoecology of the Knysna Formation. Final version available at http://sajg.geoscienceworld.org/content/113/3/241.short

\section{Discussion and synthesis}

Depositional setting

Overall, the data imply that the lignite formed in a marshy environment surrounded by significant emergent and riparian vegetation (e.g. Cyperaceae pollen). The biomarker data and the bulk $\mathrm{C} / \mathrm{N}$ ratios indicate little algal organic matter contribution to the lignite. The pyrolysis data similarly imply that a substantial proportion of the macromolecular organic matter is derived from terrestrial plants; notably leaf cuticles (cutin) and lignin monomers. The presence of the sesquiterpenoids cadalene and calamenene in the lipid extracts is strongly indicative of inputs from gynomsperm resins and is supported by the presence of Podocarpus pollen. The biomarker data are therefore primarily indicative of inputs from terrestrial/riparian plant-derived organic matter, although the $\mathrm{P}_{\mathrm{aq}}$ parameter implies the presence of some submerged or aquatic plants. Such a terrestrial wetland setting is consistent with some interpretations of the Knysna Formation (Coetzee et al., 1983). This was not a strongly anoxic environment, nor is there evidence for marine-derived organic matter (c.f. Volkman et al., 2008). This does not rule out wetland formation associated with high water tables during periods of high relative sea-level (sensu Cole and Roberts 1996), but it is not strongly supportive of a back-barrier lagoon or estuarine setting. The difficult terrain and limited exposure means that the stratigraphic relationship between Makhulu and other reported lignite exposures in the Knysna region (i.e. Veldmanspad and Brakenhill) is uncertain (Holmes et al., 2007). Such complexity serves to highlight the need to document the biostratigraphic and palaeoecological evidence within each lignite exposure. The maximum recorded altitude of the lignites is $320 \mathrm{~m}$ amsl (Veldmanspad), with the Brakenhill lignites reportedly lying at c. $259 \mathrm{~m}$ amsl (Thwaites and 
Carr, Dunajko, Bateman et al: New evidence for the age and palaeoecology of the Knysna Formation. Final version available at http://sajg.geoscienceworld.org/content/113/3/241.short

392

Jacobs, 1987) and Makhulu at $220 \mathrm{~m}$ amsl. Marker and Holmes (2002) noted the altitudinal and spatial separation of the Knysna Formation deposits at Veldmanspad, Brakenhill and Fisantshoek from the coversands, while Thwaites and Jacobs (1987) also suggested that lignite deposits may represent spatially and temporally discrete deposits. This clearly has implications for age-related and palaeoecological comparisons with the Makhulu lignite, but it is hoped that the palynological and geochemical data presented here will provide useful points of comparison.

\section{Age estimates}

The ITL analyses on the overlying coversand provide the first numerical age constraints on the Knysna Formation. While the data presented by Holmes et al (2007) demonstrated an age pre-dating the Late Pleistocene, the application of ITL pushes this minimum age back to $>1.7 \mathrm{Ma}$. The gradational boundary between the coversand and lignite units suggests that they were deposited at a similar time. The ITL result therefore implies that the Makhulu lignite may pre-date the Quaternary Period. The ITL age of $362 \pm$ 35 ka for the Barrington Road coversand (Shfd08191) is similar to the minimum ages reported by Holmes et al. (2007) for the Blaricum Heights coversands. Both sites are clearly within the coversand sheet, but their relationship with Makhulu is unclear. Their essentially mid-Pleistocene ages, in conjunction with the new Makhulu ITL data, do however support the previous inference that parts of the coversand system have been reworked during the Quaternary (Holmes et al., 2007).

The compound-specific stable isotope data also provide potential constraints on the likely age of the Makhulu lignite. The weighted mean $\left(C_{27}-C_{31}\right) n$-alkane $\delta^{13} C$ value of $-27 \%$ 
Carr, Dunajko, Bateman et al: New evidence for the age and palaeoecology of the Knysna Formation. Final version available at http://sajg.geoscienceworld.org/content/113/3/241.short

415 indicates inputs from non- $C_{3}$ vegetation sources; the end member $\delta^{13} C$ values for $C_{3}$ and $C_{4}$ 416 plant leaf waxes being -35 and $-20 \%$ respectively (Boom et al., 2002). Presently, in 417 southern Africa $\mathrm{C}_{4}$ photosynthesis is abundant in both grasses (Poaceae) and sedges (Vogel et al., 1978; Stock et al., 2004). Compound-specific stable isotope data of this type have previously been used to track the emergence of $C_{4}$ grasses during the Neogene (Freeman and Calarusso, 2001). A simple two part mixing model with the above-noted end members implies a $\mathrm{C}_{4}$ contribution to the leaf wax signal as high as $53 \%$. This approach however assumes no input from CAM (crassulacean acid metabolism) vegetation, which exhibit highly variable leaf wax $\delta^{13} \mathrm{C}$ values (ranging between -21 to $-29 \%$; Collister et al., 1994; Bi et al, 2005), and it also assumes that there is little inter-species variability in the ${ }^{13} \mathrm{C}$ offset between whole plant tissue and leaf wax $n$-alkanes (Freeman and Calarusso, 2001). There is currently little published data on CAM plant leaf wax $\delta^{13} \mathrm{C}$ variability, making this issue difficult to resolve. This result is however intriguing. Presently CAM plants are found in the southern Cape area, while grass pollen, which can dominate Quaternary and contemporary pollen spectra, is a relatively minor component of the Makhulu pollen spectrum. The efficacious dispersal of leaf waxes in the atmosphere implies that the $n$ alkane $\delta^{13} \mathrm{C}$ integrates a vegetation signal from a substantial land area (Conte and Weber, 2002; Rommerskirchen et al., 2003), and in the absence of other evidence at present, a $C_{4}$ contribution of some size represents a parsimonious interpretation. Assuming a nonnegligible contribution of $\mathrm{C}_{4}$ vegetation, an age close to or post-dating the expansion of $\mathrm{C}_{4}$ 435 grasses in the Late Miocene (c. 10 Ma; Cerling et al., 1993; Freeman and Calarusso, 2001) 436 might be inferred, with an upper age further constrained by genetic evidence for the origins 437 of $\mathrm{C}_{4}$ vegetation. Given that this origin probably lies in the Oligocene (Tipple and Pagani, 
Carr, Dunajko, Bateman et al: New evidence for the age and palaeoecology of the Knysna Formation. Final version available at http://sajg.geoscienceworld.org/content/113/3/241.short

2007), and for $C_{4}$ Cyperaceae, in the Miocene (Besnard et al., 2009), even a small $C_{4}$ contribution casts doubt on an Eocene age estimate (cf. Coetzee et al., 1983; Thwaites and Jacobs, 1987). In southern Africa Ségalen et al. (2007) concluded that the $C_{4}$ expansion occurred as late as 4-5 $\mathrm{Ma}$; an estimate supported by $\delta^{13} \mathrm{C}$ data from speleothems in the Makapansgat Valley in the summer rainfall zone (Hopley et al., 2007).

The Makhulu site lies on a coastal platform thought to have formed after a phase of uplift in the early-mid Miocene (Partridge and Maud, 1987). The early to middle Miocene was a phase of global warmth and associated high eustatic sea-levels (Haq et al., 1987; John et al., 2004; Tripati et al. 2009), representing a plausible origin for this surface. This setting is not therefore inconsistent with a Miocene or younger age, as inferred from the $n$-alkane $\delta^{13} \mathrm{C}$ data. Given the current site altitude $(220 \mathrm{~m})$, a proposed phase of later Neogene uplift (c. 150-200 m in the Pliocene; Partridge and Maud 1987) places the site close to sea-level, the water table and a potential sediment source for the overlying coversands between the late Miocene and early Pliocene (c. 10-5 Ma). Such an interpretation however ignores the significant eustatic sea-level changes during this period (Haq et al., 1987; Le Roux, 1990; John et al., 2004; Miller et al., 2005) and more recently Roberts and Brink (2002) have argued for a stronger eustatic imprint on the Western Cape coastal record. However, disentangling these eustatic and tectonic factors without additional data is clearly difficult and beyond the scope of this paper.

\section{Regional palaeoecology}

The pollen preserved at Makhulu provides some indication of the local and regional ecology. Palms are currently extinct in the southern and Western Cape, and along with the 
Carr, Dunajko, Bateman et al: New evidence for the age and palaeoecology of the Knysna Formation. Final version available at http://sajg.geoscienceworld.org/content/113/3/241.short

461

462

presence of palynomorphs of possible tropical affinity (Malvaceae, Moraceae, Sapotaceae, and Symphonia-type) the Makhulu data are suggestive of warmer and more humid conditions than the present. Interestingly, given the efficacious dispersal of saccate pollen, the proportion of Podocarpus-type does not suggest a dominant presence in local/regional environment (see also Coetzee et al., 1983), which contrasts with Holocene pollen spectra in this region (Martin, 1968). Rhus-type pollen is moderately-well dispersed (Scott, 1982), and may have been present in the local environment. Asteraceae may represent a wide range of southern African environments, but they are especially dominant in contemporary Karoo and fynbos environments. We thus infer a wetland (Cyperaceae, Aponogetonaceae), associated with a surrounding palm swamp or "gallery forest" vegetation community (palms, Symphonia-type), which in turn was surrounded by a mixed vegetation community comprising arboreal taxa (e.g. Podocarpus sp.), herbs (Cliffortia-type, Anthospermum-type) and grasses. The proportion of grasses is relatively low compared to the contemporary environment (Martin 1968), although these may be under-represented given the potentially high proportion of the locally-derived pollen from the palm swap vegetation.

This assemblage differs from previous descriptions of palynomorph assemblages from the Knysna Formation (Thiergart et al., 1963; Coetzee et al., 1983). A comparative summary is shown in table $\mathbf{5}$. Key differences include the dominance of palm pollen at Makhulu, which was either absent or tentatively identified (respectively) by Thiergart et al. (1963) and Coetzee et al. (1983). An additional sample, apparently from the Veldmanspad area, has been reported to contain high concentrations of palm pollen resembling Jubaeopsis and Nypa (Helgren and Butzer, 1977; Scott, 1995). Pollen of the distinct Nypa morphology was not identified at Makhulu. Van Zinderen Bakker (1984) reported palm 
Carr, Dunajko, Bateman et al: New evidence for the age and palaeoecology of the Knysna Formation. Final version available at http://sajg.geoscienceworld.org/content/113/3/241.short

484

485

486

487

488

489

490

491

492

493

494

495

496

497

498

499

500

501

502

503

504

505

pollen in marine sediments as young as the Late Pliocene north of Namibia, while palm pollen of the same monsulcate morphology as Makhulu Quarry has also been identified in the Miocene Elandsfontein formation (Coetzee and Rogers, 1982). Asteraceae pollen, two types of which were found in the Makhulu assemblage, has not been identified in previous studies of the Knysna Formation. Other studies of the Knysna Formation have also reported Proteaceae pollen (possibly identified at Makhulu) to be common, and grass pollen to be present, but rare (Helgren and Butzer 1977; as at Makhulu). Given these apparent differences in floral composition, the possibility that the Knysna Formation sites are diachronous cannot be ruled out. It is currently difficult to evaluate this further given the limited information on previous site locations and pollen assemblages.

Looking further afield, Coetzee (1983) interpreted proposed Miocene pollen spectra from Noordhoek (Cape Town) and the Elandsfontein Formation near Langebaanweg (Coetzee and Rogers, 1982) as indicative of mixed coniferous forests with tropical elements and varying proportions of palms. The minimum age of the pollen assemblage at Langebaanweg is constrained by overlying Varswater Formation (Franz-Odendaal et al., 2002 and references therein) and contains substantial amounts of palm pollen, as well as Podocarpus, Widdringtonia, Casuarinaceae, and Anacardiaceae. From the non-arboreal taxa, Asteraceae, Cliffortia-type, Proteaceae, and (possibly) Thymelaeceae and Stoebe-type were identified. At Noordhoek Asteraceae pollen was sparse or absent in the (presumed) earlymid Miocene parts of the record (Coetzee, 1983). During the early Pliocene increased abundances of Asteraceae pollen were associated with the loss of tropical pollen types; notably the palms (ibid; Coetzee 1986). 
Carr, Dunajko, Bateman et al: New evidence for the age and palaeoecology of the Knysna Formation. Final version available at http://sajg.geoscienceworld.org/content/113/3/241.short Additional data pertaining to the Elandsfontein Formation were presented by Cole and Roberts (1996). Here, samples from borehole LNV4 close to the Berg River contained palynomorphs characteristic of fynbos vegetation (e.g. Proteaceae, Passerina-type, Anthospermum-type), as well as Asteraceae (Brachylaena-type and undifferentiated) and Poaceae pollen. The similarities were considered sufficient to warrant association with the Langebaanweg record, although palm pollen was absent from the LNV4 samples. Scott (1995) presented data for three samples from the Pliocene Varswater Formation and identified a range of typical fynbos pollen types (Cliffortia-type, Restionaceae, Proteaceae, and Ericaceae), along with Asteraceae and grass pollen. Palm pollen was only identified in the deepest sample, which was considered transitional from the sub-tropical environments of the Elandsfontein Formation.

Palaeogene (Eocene) age estimates for the Knysna Formation have been inferred on the basis of the palynological data and notably, the absence of Ericaceae pollen (Thwaites and Jacobs, 1987). It is notable that none of the Knysna Formation sites apparently contain Ericaceae pollen, and nor was it reported at Langebaanweg (Coetzee and Rogers, 1982; Cole and Roberts, 1996). It has however been identified in the Noordhoek borehole where it is becomes progressively more abundant, along with the appearance of Asteraceae pollen in the (assumed) Late Miocene to Pliocene (Coetzee 1983). Ericaceae is also found in the Pliocene Varswater Formation assemblages (Scott, 1995). Asteraceae pollen is found at Makhulu, suggesting potential correspondence with the Noordhoek and the Langebaanweg 526 sites. The Makhulu lignite therefore displays some commonalities with the Langebaanweg 527 pollen assemblages (palm, Podocarpus-type, Poaceae, Cyperaceae, Asteraceae, Cliffortiatype, Anacardiaceae [Rhus-type]), and the lower parts of the Noordhoek record from which 
Carr, Dunajko, Bateman et al: New evidence for the age and palaeoecology of the Knysna Formation. Final version available at http://sajg.geoscienceworld.org/content/113/3/241.short

529

a similar age, broadly equivalent to the middle Miocene, may be inferred. There are, however, differences and the significant geographic separation of these regions should be borne in mind. Such an age association is not inconsistent with the geomorphic evidence or isotopic evidence at Makhulu. If the leaf wax stable isotope data are indeed influenced by a significant $\mathrm{C}_{4}$ vegetation contribution, an age more akin to the Late Miocene or younger might be inferred for Makhulu.

A Miocene to Pliocene age range inferred for the Makhulu lignite places its deposition within a key phase of the evolution and diversification of the Cape Flora, a period that apparently records a major shift in the ecology of the Western Cape; viz, the demise of the palms and tropical-affinity vegetation (Coetzee, 1983) and the diversification of many succulent Karoo and fynbos plant lineages (Richardson et al., 2001). A major change around the Late Miocene to Pliocene has been considered indicative of the progressive aridification the Western Cape, which probably related to the ongoing expansion of Antarctic ice (Coetzee, 1983; 1986; Zachos et al., 2001). This situation was also intimately related to the intensification of the Benguela upwelling system (Marlow et al., 2000), which would have reinforced summer atmospheric stability. It is difficult to assess when and how this would have affected the southern Cape/Knysna region, which even today experiences distinctly different climatic conditions to the Cape Town area. A potential $C_{4}$ signal in the $n$-alkane stable isotopes implies, to some extent, conditions akin to the contemporary summer rainfall regions of southern Africa (Vogel et al., 1978), and a response to late Neogene reductions in atmospheric $p \mathrm{CO}_{2}$ (Hopley et al., 2007). Given the pollen data presented here, vegetation of a tropical affinity may have been restricted to the vicinity of wetlands (a 'palm swamp' environment). In conjunction with evidence for an inferred absence of $C_{4}$ vegetation 
Carr, Dunajko, Bateman et al: New evidence for the age and palaeoecology of the Knysna Formation. Final version available at http://sajg.geoscienceworld.org/content/113/3/241.short

552 on the west coast (Langebaanweg) area during the early Pliocene (Franz-Odendaal et al., 2002 ) it is probable that distinct vegetation communities in the west coast and southern

554 Cape regions (and most likely contrasting climates) were established during this Late Neogene climatic/ecological re-organisation.

\section{Conclusions}

The lignitic sediments exposed at Makhulu Quarry provide a new window on

Neogene palaeoenvironments of the southern Cape coastline. Analyses using the ITL technique provide a revised minimum age of $>1.7 \mathrm{Ma}$ for the Makhulu coversands, suggesting a pre-Quaternary emplacement of the sands and lignite. Additional age constraints on the lignite are provided by the compound specific $\delta^{13} \mathrm{C}$ data, which imply a potential presence of $\mathrm{C}_{4}$ vegetation in the regional environment. The organic geochemistry of the lignite is dominated by biomarkers derived from terrestrial plants, with no significant evidence for a marine organic matter contribution. The pollen assemblage is dominated by palms, as well as a riparian vegetation suite that probably surrounded the immediate wetland site. A 'palm swamp' setting surrounded by vegetation comprising a mix of shrubs and grasses and some arboreal species (e.g. Podocarpus sp.) is inferred. These data show marked contrasts with some previous descriptions of palynology of the Knysna Formation, but show some commonalities with pollen assemblages found in the Miocene Elandsfontein Formation in the Western Cape. From this, a probable age range between the Miocene and

$5721.7 \mathrm{Ma}$ is therefore proposed for the Makhulu lignite, which might be further refined to a 573 post late Miocene age should it prove possible to demonstrate that the $n$-alkane $\delta^{13} \mathrm{C}$ signal 574 is dominated by a $\mathrm{C}_{4}$ leaf wax contribution. 
Carr, Dunajko, Bateman et al: New evidence for the age and palaeoecology of the Knysna Formation.

Final version available at http://sajg.geoscienceworld.org/content/113/3/241.short

\section{Acknowledgements}

577 The original sampling and OSL dating of the Makhulu site were funded by the Leverhulme 578 Trust (F/00 118/AF awarded to MDB) and the University of the Free State. ITL measurements were undertaken by $A D$ with support from a University of Sheffield studentship. We thank Professor Louis Scott for advice and providing copies of some of the cited literature, along with Dave Roberts, Brian Chase, and an additional reviewer for their constructive comments on earlier versions of this paper. Paul Coles is thanked for cartographic assistance.

\section{References}

Aitken, M. J. (1985) Thermoluminescence dating. Academic Press, London and New York.

Banerjee, D., Hildebrand, A.N., Murray-Wallace, C.V., Bourman, R.P., Brooke, B.P. and Blair, M. (2003) New quartz SAR-OSL ages from the stranded beach dune sequence in

Bateman, M.D., Holmes, P.J., Carr, A.S., Horton, B.P. and Jaiswal, M.K. (2004) Aeolianite and barrier dune construction spanning the last two glacial-interglacial cycles from the

Bechtel, A., Sachsenhofer, R.F., Markic, M., Gratzer, R., Lücke, A. and Püttmann, W. (2003) Paleoenvironmental implications from biomarker and stable isotope investigations on the Pliocene Velenje lignite seam (Slovenia). Organic Geochemistry, 34, 12771298. 
Carr, Dunajko, Bateman et al: New evidence for the age and palaeoecology of the Knysna Formation. Final version available at http://sajg.geoscienceworld.org/content/113/3/241.short

601

602

603

604

605

606

607

608

609

610

611

612

613

614

615

616

617

618

619

620

621

622

623

624

625

626

627

Berrío, J.C., Hooghiemstra, H., Behling, H., Botero P., and Van der Borg, W. (2002) Environmental history of the western Colombian savannas of the Llanos Orientales since the Middle Holocene from Laguna Mozambique and Chenevo: a transect synthesis. The Holocene, 12, 35-48.

Besnard, G., Muasya, A.M., Russier, F., Roalson, E.H., Salamin, N. and Christin, P.A. (2009) Phylogenomics of $\mathrm{C}_{4}$ photosynthesis in sedges (Cyperaceae): multiple appearances and genetic convergence. Molecular Biology and Evolution, 26, 1909-19.

Bi, X., Sheng, G., Lui, X., Li, C. and Fu, J. (2005) Molecular and carbon and hydrogen isotopic composition of $n$-alkanes in plant leaf waxes. Organic Geochemistry, 36, 1405-1417.

Blokker, P., Schouten, S., Van den Ende, H., De Leeuw, J.W., Hatcher, P.G. and Sinninghe Damsté, J.S. (1998) Chemical structure of algaenans from the fresh water algae Tetraedron minimum, Scenedesmus communis and Pediastrum boryanum. Organic Geochemistry, 29, 1453-1468

Boom, A., Marchant, R., Hooghiemstra, H., and Sinninghe-Damsté, J.S. (2002) $\mathrm{CO}_{2}$ and temperature-controlled altitudinal shifts of $C_{4}$ and $C_{3}$ dominated grasslands allow reconstruction of palaeo-atmospheric $\mathrm{pCO}_{2}$. Palaeogeography Palaeoclimatology Palaeoecology, 177,151-168.

Boom, A., Sinninghe-Damsté, J.S., and de Leeuw, J.W. (2005) Cutan, a common aliphatic biopolymer in cuticles of drought-adapted plants. Organic Geochemistry, 36, 595601.

Buylaert, J.P., Murray, A.S., Huot, S., Vriend, M.G.A., Vandenberghe, D., De Corte, F. and Van den haute, P. (2006) A comparison of quartz OSL and isothermal TL measurements on Chinese loess. Radiation Protection Dosimetry, 119, 474-478.

Butzer, K.W., Helgren, D.M. (1972) Late Cenozoic evolution of the Cape coast between Knysna and Cape St Francis, South Africa. Quaternary Research, 2, 143-169.

Cerling, T., Wang, Y. and Quade, J. (1993) Expansion of $C_{4}$ ecosystems as indicator of global ecological change in the Late Miocene. Nature, 361, 344-345. 
Carr, Dunajko, Bateman et al: New evidence for the age and palaeoecology of the Knysna Formation. Final version available at http://sajg.geoscienceworld.org/content/113/3/241.short

Choi, J.H., Murray, A.S., Cheong, C.-S., Hong, D.G., and Chang, H.W. (2006) Estimation of equivalent dose using quartz isothermal TL and the SAR procedure. Quaternary Geochronology, 1, 101-108.

Coetzee, J.A. (1983) Intimations on the Tertiary vegetation of southern Africa. Bothalia, 14, 345-354.

Coetzee, J.A. (1986) Palynological evidence for major vegetation and climatic-change in the Miocene and Pliocene of the southwestern Cape. South African Journal of Science, $82,71-72$

Coetzee, J.A. and Rogers, J. (1982) Palynological and lithological evidence for the Miocene Palaeoenvironment in the Saldanha region, South Africa. Palaeogeography Palaeoclimatology Palaeoecology, 38, 71-85

Coetzee, J.A., Scholtz, A. and Deacon, H.J. (1983) Palynological studies and vegetation history of the fynbos. In Deacon, H.J et al. Fynbos Palaeoecology: a preliminary synthesis, CSIR Report 75, p156-173.

Cole, D.I. and Roberts, D.L. (1996) Lignite from the western coastal plain of South Africa. Journal of African Earth Sciences, 23, 95-117

Collister, J.W., Rieley, G., Stern, B., Eglinton, G. and Fry, B. (1994) Compound-specific $\delta^{13} C$ analyses of leaf lipids from plants with differing carbon dioxide metabolisms. Organic Geochemistry, 21, 619-627.

Conte, M.H. and Weber, J.C. (2002) Plant biomarkers in aerosols record isotopic discrimination of terrestrial photosynthesis. Nature 417, 639-641

Du Toit, A.L. (1956) The Geology of South Africa (Third Edition). Oliver and Boyd, Edinburgh.

Eglinton, G. and Hamilton, R. (1967) Leaf epicuticular waxes. Science, 156, 1322-1335

Eglinton, T.I. and Eglinton, G. (2008) Molecular proxies for paleoclimatology. Earth and Planetary Science Letters, 275, 1-16 
Carr, Dunajko, Bateman et al: New evidence for the age and palaeoecology of the Knysna Formation.

Final version available at http://sajg.geoscienceworld.org/content/113/3/241.short

Ficken, K.J., Li, B., Swain, D.L. and Eglinton, G. (2000) An $n$-alkane proxy for the sedimentary input of submerged/floating freshwater aquatic macrophytes. Organic Geochemistry, 31, 745-749

Franklin, A.D. (1997) On the interaction between the rapidly and slowly bleaching peaks in the TL glow curves of quartz. Journal of Luminescence, $75,71-76$

Franz-Odendaal, T.A., Lee-thorp, J.A. and Chinsamy, A. (2002) Evidence for the lack of $\mathrm{C}_{4}$ grassland expansions during the Early Pliocene at Langebaanweg, South Africa. Paleobiology, 28, 378-388

Freeman, K.H. and Calarusso, L.A. (2001) Molecular and isotopic records of $\mathrm{C}_{4}$ grassland expansion in the Late Miocene. Geochimica et Cosmochimica Acta, 65, 1439-1454.

Galbraith, R.F., Roberts, R.G., Laslett, G.M., Yoshida, H. and Olley, J.M. (1999). Optical dating of single and multiple grains of quartz from Jimnium rock shelter, northern Australia, Part 1, experimental design and statistical models. Archaeometry, 41, 229-364

Gupta, N.S., Michels, R., Briggs, D.E.G., Collinson, M.E., Evershed, R.P. and Pancost, R.D. (2007) Experimental evidence for the formation of geomacromolecules from plant leaf lipids. Organic Geochemistry, 38, 28-36

Harley, M.M. and Baker, W.J. (2001) Pollen aperture morphology in Arecaceae: application within phylogenetic analyses, and a summary of the fossil record of palm like pollen. Grana, 40, 45-77.

Haq, B.V., Hardenbol, J. and Vail, P.R. (1987) Chronology of fluctuating sea levels since the Triassic. Science, 235, 1156-1167.

Helgren, D.M. and Butzer, K.W. 1977. Paleosols of the southern Cape coast, South Africa: Implications for laterite definition, genesis and age. Geographical Review, 67, 430445.

Holmes, P.J., Bateman, M.D., Carr, A.S. and Marker, M.E. (2007) The place of the aeolian coversands in the geomorphic evolution of the southern Cape coast, South Africa. South African Journal of Geology, 110, 127-138 
Carr, Dunajko, Bateman et al: New evidence for the age and palaeoecology of the Knysna Formation. Final version available at http://sajg.geoscienceworld.org/content/113/3/241.short

680

681

682

683

684

685

686

687

688

689

690

691

692

693

694

695

696

697

698

699

700

701

702

703

704

705

706

Hopley, P.J., Marshall, J.D., Weeden, G.P., Latham, A.G., Herries, A.I.R. and Kuykendall, K.L. (2007) Orbital forcing and the spread of $C_{4}$ grasses in the late Neogene: stable isotope evidence from South African speleothems. Journal of Human Evolution, 53, 620-634.

Huot, S., Buylaert, J.P. and Murray A.S. (2006) Isothermal thermoluminescence signals from quartz. Radiation Measurements, 41, 796-802.

Jacobs, E.O. (1992) Lithostratigraphy of the Knysna Formation. South African Committee for Stratigraphy Lithostratigraphic Series 17, Government Printer, Pretoria.

Jain, M., Duller, G.A.T. and Wintle, A.G. (2007) Dose response, thermal stability and optical bleaching of the $310^{\circ} \mathrm{C}$ isothermal TL signal in quartz. Radiation Measurements, $\mathbf{4 2}$, 1285-1293.

John, C.M., Karner, G.D. and Mutti, M. (2004) $\delta^{18} \mathrm{O}$ and Marion Plateau backstripping: Combining two approaches to constrain late middle Miocene eustatic amplitude. Geology, 32, 829-832

Linder, H.P. (2003) The radiation of the Cape flora, southern Africa. Biological Reviews of the Cambridge Philosophical Society, 78, 597-638.

Le Roux, F.G. (1990) Palaeontological correlation of Cenozoic marine deposits of the southeastern, southern and western coasts, Cape Province. South African Journal of Geology, 93, 514-518.

Logan, G.A., Boon, J.J. and Eglinton G. (1993) Structural biopolymer preservation in Miocene leaf fossils from the Clarkia site, northern Idaho. Proceedings of the National Academy of Sciences of the United States of America, 90, 2246-2250.

Ledru, M.P. (2001) Late Holocene rainforest disturbance in French Guiana. Review of Palaeobotany and Palynology, 115, 161-176

Marker, M.E. and Holmes, P.J. (2002) The distribution and environmental implications of coversand depsots in the southern Cape. South African Journal of Geology, 105, 135146. 
Carr, Dunajko, Bateman et al: New evidence for the age and palaeoecology of the Knysna Formation.

Final version available at http://sajg.geoscienceworld.org/content/113/3/241.short

707

708

709

710

711

712

713

714

715

716

717

718

719

720

721

722

723

724

Marker, M.E. and Holmes, P.J. (2005) Landscape evolution and landscape sensitivity: the case of the southern Cape. South African Journal of Science, 101, 53-60.

Marlow, J.R., Lange, C.B., Wefer, G. and Rosell-Melé, A. (2000) Upwelling intensification as part of the Pliocene-Pleistocene climate transition. Science, 290, 2288-2291.

Martin A.R.H (1968) Pollen analysis of Groenvlei lake catchments, Knysna. Review of Palaeobotany and Palynology, 7, 107-144.

Meyers, P.A. and Lallier-Vergés, E. (1999) Lacustrine sedimentary organic matter records of Late Quaternary palaeoclimates. Journal of Paleolimnology, 21, 345-372.

Miller, K.G., Kominz, M.A. Browning, J.V., Wright, J.D., Mountain, G.S., Katz, M.E., Sugarman, P.J., Cramer, B.S., Christie-Blick, N. and Pekar, S.F. (2005) The Phanerozoic record of global sea-level change. Science, 310, 1293 - 1298

Murray, A.S., and Wintle, A.G. (2000) Luminescence dating of quartz using an improved single-aliquot regenerative-dose protocol. Radiation Measurements, 32, 57-73.

Nip, M., Tegelaar, E.W., de Leeuw J.W. and Schenck, P.A. (1986) A new non-saponifiable highly aliphatic and resistant biopolymer in plant cuticles. Naturwissenschaften, 73, 579-585.

Otto, A., Simoniet, B.R.T. and Rember, W.C. (2005) Conifer and angiosperm biomarkers in clay sediments and fossil plants from the Miocene Clarkia Formation, Idaho, USA. Organic Geochemistry, 36, 907-922.

Pancost, R.D. and Boot, C.S. (2004) The palaeoclimatic utility of terrestrial biomarkers in marine sediments. Marine Chemistry, 92, 239-261.

Pancost, R.D., Steart, D.S., Handley, L., Collinson, M.E., Hooker, J.J., Scott, A.C., Grassineau, N.V. and Glasspool, I.J. (2007) Increased terrestrial methane cycling at the Palaeocene-Eocene thermal maximum. Nature, 449, 332-335

Partridge, A.D. (1978) Palynology of the late Tertiary sequence at Site 365, Leg 40. Deep Sea Drilling Project Initial Reports, 40, 953-961. 
Carr, Dunajko, Bateman et al: New evidence for the age and palaeoecology of the Knysna Formation.

Final version available at http://sajg.geoscienceworld.org/content/113/3/241.short

Partridge, T.C. and Maud, R.R. (1987) Geomorphic evolution of southern Africa since the Mesozoic. South African Journal of Geology, 90, 179-208.

Phillips, J.F.V. (1927) Fossil Widdringtonia in lignite of the Knysna Series, with a note on fossil leaves of several other species. South African Journal of Science, 24, 188-197

Richardson, J.E., Weitz, F.M., Fay, M.F., Cronk, Q.C.B., Linder, H.P., Reeves, G. and Chase, M.W. (2001) Rapid and recent origin of species richness in the Cape flora of South Africa. Nature, 412, 181-183.

Roberts, D.L. and Brink, J.S. (2002) Dating and correlation of Neogene coastal deposits in the Western Cape (South Africa): implications for Neotectonism. South African Journal of Geology, 105, 337-352

Rommerskirchen, F., Eglinton, G., Dupont, L., Güntner, U., Wenzel C. and Rullkötter, J. (2003) A north to south transect of Holocene southeast Atlantic continental margin sediments: relationship between aerosol transport and compound-specific $\delta^{13} \mathrm{C}$ plant biomarker and pollen records. Geochemistry, Geophysics, Geosystems 4 (12) 1101.

Scott, L. (1982) Late Quaternary fossil pollen grains from the Transvaal, South Africa. Review of Palaeobotany and Palynology 36, 241-278

Scott, L (1995) Pollen evidence for vegetational and climatic change in southern Africa during the Neogene and Quaternary. In: Vrba, E.S., Denton, G.H., Partridge, T.C. and Burckle, L.H. (eds). Palaeoclimate and evolution with emphasis on human origins. Yale University Press, pp 65-76.

Ségelan, L., Lee-Thorp, J.A. and Cerling, T. (2007) Timing of $C_{4}$ grass expansion across subSaharan Africa. Journal of Human Evolution, 53, 549-559.

Skvarla,J.J., DeVore, M.L., and Chissoe, WF. (2005) Lophate sculpturing of Vernonieae (Compositae) pollen. Review of Palaeobotany and Palynology, 133, 51-68

Stefanovaa, M., Markovab, K., Marinova, S. and Simoneit, B.R.T. (2005) Molecular indicators for coal-forming vegetation of the Miocene Chukurovo lignite, Bulgaria. Fuel, 84, 1830-1838. 
Carr, Dunajko, Bateman et al: New evidence for the age and palaeoecology of the Knysna Formation.

Final version available at http://sajg.geoscienceworld.org/content/113/3/241.short

Street-Perrott, F.A., Ficken, K.J., Huang, Y. and Eglinton, G. (2004) Late Quaternary changes in carbon cycling on Mt. Kenya, East Africa: an overview of the $\delta^{13} \mathrm{C}$ record in lacustrine organic matter. Quaternary Science Reviews, 23, 861-879.

Stock, W.D., Chuba, D.K. and Verboom, G.A. (2004) Distribution of South African $C_{3}$ and $C_{4}$ species of Cyperaceae in relation to climate and phylogeny. Austral Ecology, 29, 313319

Thiergart, F., Frantz, U. and Raukopf, K. (1963) Palynologische untersuchungen von Tertiärkohlen und einer oberflächen-probe nahe Knysna, Südafrika. Advancing Frontiers in Plant Science, 4, 151-178.

Thwaites, R.N. and Jacobs, E.O. (1987) The Knysna Lignites: a review of their position within the geomorphological development of the southern Cape Province, South Africa. South African Journal of Geology, 90, 137-146

Tipple, B.J. and Pagani, M. (2007) The early origins of terrestrial $C_{4}$ photosynthesis. Annual Reviews of Earth and Planetary Science, 35, 435-461

Tripati, A.K., Roberts, C.D. and Eagle, R.A. (2009) Coupling of $\mathrm{CO}_{2}$ and ice sheet stability over major climate transitions of the last 20 million years. Science, 326, 1394 - 1397

Vandenberghe, D.A.G., Jain, M. and Murray, A.S. (2009) Equivalent dose determination using a quartz isothermal TL signal. Radiation Measurements, 44, 439-444.

Van Zinderen Bakker, E.M. (1984) Palynological evidence for Late Cenozoic arid conditions along the Namibia coast from Hole 532 and 530A, Leg 75, Deep Sea Drilling Project. Deep Sea Drilling Project Initial Reports, 75, 763-768

Vogel, J.C., Fuls, A. and Ellis, R.P. (1978) The geographical distribution of Kranz grasses in South Africa. South African Journal of Science, 74, 209-215.

Volkman, J.K., Revill, A.T., Holdsworth, D.G. and Fredericks, D. (2008) Organic matter sources in an enclosed coastal inlet assessed using lipid biomarkers and stable isotopes. Organic Geochemistry, 39, 689-710 
Carr, Dunajko, Bateman et al: New evidence for the age and palaeoecology of the Knysna Formation.

Final version available at http://sajg.geoscienceworld.org/content/113/3/241.short

Wintle, A.G. and Murray, A.S. (2006) A review of quartz optically stimulated luminescence characteristics and their relevance in single-aliquot regeneration dating protocols. Radiation Measurements, 41, 369-391

Yang, H., Huang, Y., Leng, Q., Le Page B.A. and Williams, C.J. (2005) Biomolecular preservation of Tertiary Metasequoia fossil Lagerstätten revealed by comparative pyrolysis analysis. Review of Palaeobotany and Palynology, 134, 237-256.

Zachos, J.C., Pagani, M., Sloan, L., Thomas, E. and Billups, K. (2001) Trends, rhythms, and abberations in global climate 65 Ma to present. Science, 292, 686-693.

\section{Table Captions}

Table 1: Details of the SAR ITL protocol used in this study (following Choi et al. 2006). All heating was carried out at $2^{\circ} \mathrm{C} \mathrm{s}^{-1} .{ }^{*} \mathrm{Di}$ is $0 \mathrm{~Gy}$ in the first cycle $(\mathrm{i}=0)$ when the natural dose is measured. Preheat $\mathrm{T}$ and ITL T were determined experimentally (see text).

\begin{tabular}{|c|c|c|}
\hline Stage & Treatment & Record \\
\hline 1 & Administer regeneration dose $\mathrm{D}_{\mathrm{i}}{ }^{*}$ & - \\
2 & Preheat for $10 \mathrm{~s}$ at $\mathrm{T}^{\circ} \mathrm{C}$ & - \\
3 & ITL at $\mathrm{T}^{\circ} \mathrm{C}$ for $500 \mathrm{~s}$ & ITL $L_{i}$ \\
4 & Give fixed test dose $\mathrm{D}_{\mathrm{t}}$ & - \\
5 & Preheat for $10 \mathrm{~s}$ at $\mathrm{T}^{\circ} \mathrm{C}$ & - \\
6 & ITL at $\mathrm{T}^{\circ} \mathrm{C}$ for $500 \mathrm{~s}$ & ITL $T_{i}$ \\
7 & Repeat steps $1-6$ & - \\
\hline
\end{tabular}

Table 2: Details of the OSL age determinations including dose rate data, equivalent doses and resulting ages

${ }^{*} D_{\mathrm{e}}$ values used to calculate a minimum age excludes aliquots which were saturated and as such represents a conservative estimation of minimum palaeodose

\# published in Holmes et al (2007)

\$ determined using beta counting

Derived using the 'central age model' (Galbraith et al., 1999) and reported with 1 standard error

\begin{tabular}{|c|c|c|c|c|c|c|c|c|c|}
\hline \multicolumn{3}{|c|}{ Sample Details } & \multicolumn{3}{|c|}{ Dosimetry Data } & \multicolumn{2}{|c|}{ OSL Data } & \multicolumn{2}{|c|}{ ITL Data } \\
\hline Site & Lab code & $\begin{array}{l}\text { Depth } \\
\text { (m) }\end{array}$ & $\begin{array}{c}\text { Cosmic } \\
\text { dose } \\
\left(\mu G y a^{-1}\right)\end{array}$ & $\begin{array}{c}\text { Water } \\
\text { content } \\
(\%)\end{array}$ & $\begin{array}{c}\text { Total dose } \\
\text { rate } \\
\left(\mu G y \mathrm{a}^{-1}\right)\end{array}$ & $\begin{array}{c}\text { Average } \\
D_{\mathrm{e}^{\sim}} \\
\text { (Gy) }\end{array}$ & Age (ma) & $\begin{array}{c}\text { Average } \\
D_{\mathrm{e}} \sim \\
\text { (Gy) }\end{array}$ & Age (Ma) \\
\hline $\begin{array}{l}\text { Barrington } \\
\text { Road }\end{array}$ & Shfd08191 & 3 & $170 \pm 8$ & 4.2 & $804 \pm 66^{\$}$ & $232 \pm 6$ & $\begin{array}{c}0.29 \pm \\
0.02\end{array}$ & $291 \pm 15$ & $0.36 \pm 0.04$ \\
\hline $\begin{array}{l}\text { Makhulu } \\
\text { Quarry }\end{array}$ & Shfd04287 & 1.6 & $174 \pm 9$ & 4.8 & $475 \pm 20^{\#}$ & $\begin{array}{c}248 \pm \\
11^{*}\end{array}$ & $>0.52^{\#}$ & $\begin{array}{c}806 \pm \\
58^{*}\end{array}$ & $>1.70$ \\
\hline
\end{tabular}


Carr, Dunajko, Bateman et al: New evidence for the age and palaeoecology of the Knysna Formation. Final version available at http://sajg.geoscienceworld.org/content/113/3/241.short

807

Table 3: Bulk carbon and nitrogen contents, and $\delta^{13} \mathrm{C}$ of the sampled lignite, along with $n$-alkane derived indices from the apolar solvent extraction.

\begin{tabular}{|c|c|}
\hline Total organic carbon (\%) & 38.5 \\
\hline $\boldsymbol{\delta}^{13} \mathbf{C}_{\text {TOc }}(\%)$ & -26.6 \\
\hline Total Nitrogen (\%) & 0.8 \\
\hline TOC/TN & 45 \\
\hline$n$-alkane Carbon Preference Index (CPI: $\mathbf{C}_{\mathbf{2 5}}-\mathbf{C}_{\mathbf{3 4}}$ ) & 4.57 \\
\hline $\boldsymbol{n}$-alkane average chain length $\left(\mathbf{C}_{\mathbf{2 3}} \mathbf{C}_{\mathbf{3 3}}\right)$ & 27.9 \\
\hline $\mathbf{P}_{\text {aq }}$ (Ficken et al, 2000) & 0.42 \\
\hline
\end{tabular}

Table 4: Compound specific $\delta^{13} \mathrm{C}$ data. Weighted mean $n$-alkane $\delta^{13} \mathrm{C}$ is weighted by relative peak area.

\begin{tabular}{|c|c|c|}
\hline Compound & $\begin{array}{l}\text { Concentration } \\
\qquad\left(\mu \mathrm{g} \mathrm{g}^{-1}\right)\end{array}$ & $\delta^{13} \mathrm{C}(\%)$ \\
\hline $\mathrm{C}_{25}$ alkane & 11.3 & -25.6 \\
\hline $\mathrm{C}_{26}$ alkane & 2.57 & -26.6 \\
\hline $\mathrm{C}_{27}$ alkane & 8.98 & -25.2 \\
\hline $\mathrm{C}_{28}$ alkane & 2.09 & -25.8 \\
\hline $\mathrm{C}_{29}$ alkane & 8.46 & -28.1 \\
\hline $\mathrm{C}_{31}$ alkane & 13.9 & -28.0 \\
\hline $\mathrm{C}_{33}$ alkane & 2.06 & -27.3 \\
\hline \multicolumn{2}{|c|}{ Weighted mean $n$-alkane } & -27.0 \\
\hline Des-A-Lupane & 16.0 & -24.4 \\
\hline $\begin{array}{c}17 \beta 21 \beta \\
\text { 30normoretane }\end{array}$ & 1.99 & -25.2 \\
\hline $\begin{array}{c}17 \beta 21 \beta \\
\text { Homohopane }\end{array}$ & 0.77 & -20.6 \\
\hline
\end{tabular}


Carr, Dunajko, Bateman et al: New evidence for the age and palaeoecology of the Knysna Formation.

Final version available at http://sajg.geoscienceworld.org/content/113/3/241.short

Table 5: Comparative table showing the Makhulu pollen data in relation previous reports of the Knysna Formation and Western Cape sites reported by Coetzee and Rogers (1982) and Cole and Roberts (1996) * Only pollen types listed in paper footnotes and/or referred to in Scott (1995) are shown here.

\begin{tabular}{|c|c|c|c|c|c|c|}
\hline \multirow[b]{2}{*}{ Pollen type } & \multicolumn{4}{|c|}{ Knysna Formation } & \multicolumn{2}{|c|}{$\begin{array}{c}\text { West Coast } \\
\text { (Elandsfontein } \\
\text { Formation: Miocene) }\end{array}$} \\
\hline & $\begin{array}{l}\text { Makhulu } \\
\text { quarry }\end{array}$ & $\begin{array}{l}\text { Coetzee et } \\
\text { al. (1983) }\end{array}$ & $\begin{array}{c}\text { Thiergart et } \\
\text { al. (1963) }\end{array}$ & $\begin{array}{c}\text { Helgren } \\
\text { and } \\
\text { Butzer } \\
(1977)^{*}\end{array}$ & $\begin{array}{c}\text { Cole and } \\
\text { Roberts } \\
(1996)\end{array}$ & $\begin{array}{c}\text { Coetzee } \\
\text { and } \\
\text { Rogers } \\
\text { (1982) }\end{array}$ \\
\hline Palm (Arecaceae) & $Y(37 \%)$ & $?$ & & $\mathrm{Y}$ & & $Y$ \\
\hline Cupressaceae & & & & & & $Y$ \\
\hline Podocarpus-sp & $Y(3.7 \%)$ & $\mathrm{Y}$ & $Y$ & & & $\mathrm{Y}$ \\
\hline Sapotaceae & $Y(6.6 \%)$ & & & & & \\
\hline Symphonia-type & Y (5.0\%) & & & & & \\
\hline Casuarinaceae & & $Y$ & & & & $Y$ \\
\hline Cunonia?-type & $Y(1.2 \%)$ & & & & & \\
\hline Oleaceae & & & $Y$ & & & $Y$ \\
\hline Ulmaceae & & & & & & Y \\
\hline Poaceae & Y (4.6\%) & & & Y (rare) & Y & $Y$ \\
\hline Euphorbiaceae & $?(0.4 \%)$ & & $Y$ ? & & & $Y$ \\
\hline Asteraceae & $Y(2.9 \%)$ & & & & $Y$ & $Y$ \\
\hline Anacardiaceae & $Y(2.5 \%)$ & & $Y$ & & & $Y$ \\
\hline Rhus-type & $Y(0.4 \%)$ & $Y$ & $Y$ & & $Y$ & $?$ \\
\hline Rubiaceae & $Y(0.4 \%)$ & $?$ & & & & $Y$ \\
\hline $\begin{array}{l}\text { Anthospermum- } \\
\text { type }\end{array}$ & $Y(0.4 \%)$ & $?$ & & & $Y$ & $?$ \\
\hline Myricaceae & $Y(1.2 \%)$ & & & & & \\
\hline Cliffortia-type & $Y(0.4 \%)$ & $Y$ & & & $Y$ & $Y$ \\
\hline Cyperaceae & $Y(6.7 \%)$ & & $Y$ & & $Y$ & \\
\hline \multicolumn{7}{|l|}{ Ericaceae } \\
\hline Proteaceae & $?(0.4 \%)$ & $Y$ & $Y$ & $Y$ & $Y$ & $Y$ \\
\hline Restionaceae & & $Y$ & $Y$ & & $Y$ & \\
\hline Thymelaceae & & & & & & $?$ \\
\hline Myrtaceae & & $Y$ & & & & \\
\hline
\end{tabular}


Carr, Dunajko, Bateman et al: New evidence for the age and palaeoecology of the Knysna Formation. Final version available at http://sajg.geoscienceworld.org/content/113/3/241.short 